\title{
ORCHIDEE-SOM: modeling soil organic carbon (SOC) and dissolved organic carbon (DOC) dynamics along vertical soil profiles in Europe
}

\author{
Marta Camino-Serrano ${ }^{1,2}$, Bertrand Guenet ${ }^{3}$, Sebastiaan Luyssaert ${ }^{4}$, ${\text { Philippe } \text { Ciais }^{3} \text {, Vladislav Bastrikov }}^{3}$, \\ Bruno De Vos ${ }^{5}$, Bert Gielen ${ }^{6}$, Gerd Gleixner ${ }^{7}$, Albert Jornet-Puig ${ }^{3}$, Klaus Kaiser ${ }^{8}$, Dolly Kothawala ${ }^{9}$, \\ Ronny Lauerwald $^{10}$, Josep Peñuelas ${ }^{1,2}$, Marion Schrumpf ${ }^{7}$, Sara Vicca ${ }^{6}$, Nicolas Vuichard ${ }^{3}$, David Walmsley ${ }^{11}$, and \\ Ivan A. Janssens ${ }^{6}$ \\ ${ }^{1}$ CREAF, Cerdanyola del Vallès, 08193, Catalonia, Spain \\ ${ }^{2}$ CSIC, Global Ecology Unit CREAF-CSIC-UAB, Bellaterra 08193, Catalonia, Spain \\ ${ }^{3}$ Laboratoire des Sciences du Climat et de l'Environnement, LSCE/IPSL, CEA-CNRS-UVSQ, Université Paris-Saclay, \\ 91191 Gif-sur-Yvette, France \\ ${ }^{4}$ Department of Ecological Sciences, Free University Amsterdam (VUAmsterdam), De Boelelaan 1085, \\ 1081 HV Amsterdam, the Netherlands \\ ${ }^{5}$ INBO, Research Institute for Nature and Forest, Gaverstraat 4, 9500 Geraardsbergen, Belgium \\ ${ }^{6}$ Department of Biology, Research Group of Plant and Vegetation Ecology, University of Antwerp, Universiteitsplein 1, \\ 2610 Wilrijk, Belgium \\ ${ }^{7}$ Max Planck Institute for Biogeochemistry, Hans-Knöll-Straße 10, 07745 Jena, Germany \\ ${ }^{8}$ Soil Science and Soil Protection, Martin Luther University Halle-Wittenberg, von-Seckendorff-Platz 3, \\ 06120 Halle (Saale), Germany \\ ${ }^{9}$ Department of Limnology, Evolutionary Biology Centre, Norbyvägen 18D, Uppsala University, Uppsala, 75236, Sweden \\ ${ }^{10}$ Department of Mathematics, College of Engineering, Mathematics and Physical Sciences, University of Exeter, \\ Exeter EX4 4QE, UK \\ ${ }^{11}$ Institute of Ecology, Faculty of Sustainability, Leuphana University of Lüneburg, Universitätsallee 1, \\ 21335 Lüneburg, Germany
}

Correspondence: Marta Camino-Serrano (martacs32@gmail.com) and Bertrand Guenet (bertrand.guenet@1sce.ipsl.fr)

Received: 13 October 2017 - Discussion started: 16 November 2017

Revised: 26 January 2018 - Accepted: 2 February 2018 - Published: 15 March 2018

\begin{abstract}
Current land surface models (LSMs) typically represent soils in a very simplistic way, assuming soil organic carbon (SOC) as a bulk, and thus impeding a correct representation of deep soil carbon dynamics. Moreover, LSMs generally neglect the production and export of dissolved organic carbon (DOC) from soils to rivers, leading to overestimations of the potential carbon sequestration on land. This common oversimplified processing of SOC in LSMs is partly responsible for the large uncertainty in the predictions of the soil carbon response to climate change. In this study, we present a new soil carbon module called ORCHIDEESOM, embedded within the land surface model ORCHIDEE, which is able to reproduce the DOC and SOC dynamics in
\end{abstract}

a vertically discretized soil to $2 \mathrm{~m}$. The model includes processes of biological production and consumption of SOC and DOC, DOC adsorption on and desorption from soil minerals, diffusion of SOC and DOC, and DOC transport with water through and out of the soils to rivers. We evaluated ORCHIDEE-SOM against observations of DOC concentrations and SOC stocks from four European sites with different vegetation covers: a coniferous forest, a deciduous forest, a grassland, and a cropland. The model was able to reproduce the SOC stocks along their vertical profiles at the four sites and the DOC concentrations within the range of measurements, with the exception of the DOC concentrations in the upper soil horizon at the coniferous forest. However, the 
model was not able to fully capture the temporal dynamics of DOC concentrations. Further model improvements should focus on a plant- and depth-dependent parameterization of the new input model parameters, such as the turnover times of DOC and the microbial carbon use efficiency. We suggest that this new soil module, when parameterized for global simulations, will improve the representation of the global carbon cycle in LSMs, thus helping to constrain the predictions of the future SOC response to global warming.

\section{Introduction}

The soil is the largest terrestrial carbon pool and its response to global warming is thus crucial for the global carbon (C) cycle and its feedback to climate change (Jobbagy and Jackson, 2000; Todd-Brown et al., 2014). Among other things, Earth system models aim to predict the vulnerability of the global carbon cycle to climate change. However, to date the response of the soil organic carbon (SOC) pool and fluxes to climate change remains highly uncertain, mainly because the mechanistic understanding of soil processes remains imperfect and because new knowledge is not rapidly incorporated into these global models (Bradford et al., 2016; Schmidt et al., 2011; Todd-Brown et al., 2013; Wieder et al., 2015). In this sense, many authors have called for a more realistic representation of what governs SOC dynamics and transport within land surface models (LSMs), which are the land component of Earth system models (Battin et al., 2009; Nishina et al., 2014; Schmidt et al., 2011; Todd-Brown et al., 2014; Wieder et al., 2015). Among the suggested model improvements, the representation of the vertical SOC distribution and dissolved organic carbon (DOC) in the soil and the lateral export of carbon out of the soil are most likely to considerably improve model simulations.

Deep ( $>1 \mathrm{~m}$ ) soil $\mathrm{C}$ accounts for more than half of the global SOC stocks and it is stabilized for long periods (from decades to millennia; Jobbagy and Jackson, 2000; Koarashi et al., 2012). Recent studies have, however, shown that environmental changes may destabilize deep SOC, for instance by accelerating decomposition when labile organic carbon is provided to the microbial community (Fontaine et al., 2007), making it highly vulnerable to the primary production increase associated with global change or to the modification of root profiles due to land use change (Hurtt et al., 2011; Norby et al., 2005; Ryan et al., 2017). Two main processes cause the vertical movement of SOC into deep soils: dispersal of SOC during mixing, which is represented in models as a diffusion process and is mainly due to bioturbation caused by animal and plant activity in soil and to cryoturbation in permafrost soils, and advection, which is the transport of carbon with the liquid phase moving through the soil, affecting only the soluble C pool (Braakhekke et al., 2013). Nevertheless, the flux of $\mathrm{C}$ into deep layers is difficult to model because multiple mechanisms co-occur, which hampers the isolation of their effects from SOC profile measurements (Braakhekke et al., 2013).

DOC is one of the main sources of subsoil SOC and, at the same time, an important substrate for microorganisms in deep soils, particularly under humid conditions (Kaiser and Kalbitz, 2012; Neff and Asner, 2001; Rumpel and KogelKnabner, 2011). DOC may be strongly retained in mineral soils by adsorption and may thus contribute to SOC sequestration (Schrumpf et al., 2013). On the other hand, because soil microbial activity in deep layers is limited by fresh and labile substrates, the input of fresh DOC may stimulate SOC decomposition in deep soils (Fontaine et al., 2007; Rumpel and Kogel-Knabner, 2011). Therefore, besides transport in the soil column by advection and diffusion, two main processes control DOC dynamics: (1) biological production and consumption and (2) adsorption to and desorption from soil minerals, and these processes in turn impact SOC cycling along the soil profile (Dwivedi et al., 2017; Kaiser and Kalbitz, 2012).

Despite the importance of deep soil carbon, to date only one LSM (CLM4) incorporates mechanisms for the vertical mixing and subsequent stabilization of carbon (Koven et al., 2013). The representation of SOC in LSMs is generally highly simplified, with a single-layer box modeling approach and without representation of a soluble pool of carbon (ToddBrown et al., 2013). This approach assumes that deeper SOC and DOC do not play an active role in the $\mathrm{C}$ cycle and thus hampers the prediction of the soil feedback to global warming. Hence, it seems clear that more realistic representations of the mechanisms controlling SOC stocks and DOC processing and transport along the soil profile are necessary to predict the vulnerability of deep SOC to climate change in order to accurately model the future soil carbon stock trajectories.

Furthermore, the DOC that is not retained in the soils is displaced along the land-aquatic continuum (Battin et al., 2009; Le Quéré et al., 2014) and is a main substrate for freshwater decomposition. Modeling the DOC exported from soils to aquatic systems is thus important for accurate estimations of $\mathrm{C}$ budgets, as it corresponds to a fraction of the carbon taken up from the atmosphere that is not sequestered in soils. Moreover, this fraction is altered due to anthropogenic activity (Le Quéré et al., 2015; Regnier et al., 2013). Although the magnitude of $\mathrm{C}$ losses through DOC export is very small compared to the gross ecosystem carbon fluxes (between 2 and $5 \%$ of soil heterotrophic respiration; after Regnier et al., 2013; Schulze et al., 2009), neglecting the DOC export from land in LSMs can lead to a systematic overestimation of the SOC stocks and of the SOC sink (Jackson et al., 2002; Janssens et al., 2003).

Several models can predict DOC concentrations and export on the site, landscape, or catchment scale (Ahrens et al., 2015; Futter et al., 2007; Gjettermann et al., 2008; Neff and Asner, 2001; Jutras et al., 2011; Michalzik et al., 2003; Ota 
et al., 2013; Tian et al., 2015; Wu et al., 2014). These models differ in the definitions of the soil $\mathrm{C}$ pools (from turnover times to chemically differentiated fractions), the level of detail in the process formulation (e.g., from simple first-order kinetics to nonlinear relationships, including or not including sorption to soil minerals), and the spatial and temporal resolution (from site to global and from hourly to annual or longer timescales). While these models have been successfully tested and are able to reasonably simulate DOC dynamics, at present only two models exist that can predict DOC export from soil on the global scale (Langerwisch et al., 2016; McGuire et al., 2010) and there is no global LSM embedded within an Earth system model that represents a vertically resolved module of SOC and DOC production, consumption, sorption, and transport.

The purpose of this paper is to describe the new soil $\mathrm{C}$ module ORCHIDEE-SOM, embedded in the LSM ORCHIDEE, which is able to reproduce the SOC and DOC dynamics in a vertically discretized soil down to $2 \mathrm{~m}$, which is consistent with water transport and soil thermics. We also perform a first evaluation of the new soil module ability to reproduce SOC stocks and DOC concentration dynamics by comparing model predictions with respective field observations at four European experimental sites with different vegetation covers and soil properties. If the model structure is valid, ORCHIDEE-SOM should be able to reproduce not only the values of DOC and SOC concentrations within the range of the observations, but also the internal soil processes that drive the site-specific differences in SOC stocks following differences in soil texture, vegetation, and climate and the decrease in SOC and DOC down the soil profile.

\section{Model developments}

ORCHIDEE-SOM is an extension to the soil module in ORCHIDEE based on the ORCHIDEE version SVN r3340. ORCHIDEE represents the principal processes influencing the carbon cycle (photosynthesis, ecosystem respiration, soil carbon dynamics, fire, etc.) and energy exchanges in the biosphere (Krinner et al., 2005). It consists of two modules: SECHIBA, describing the fast processes of energy and water exchanges between the atmosphere and the biosphere at a time step of $30 \mathrm{~min}$ (de Rosnay et al., 2002), and STOMATE, which calculates the phenology and carbon dynamics of the terrestrial biosphere at a time step of 1 day. ORCHIDEE represents vegetation globally using 13 plant functional types (PFTs): one PFT for bare soil, eight for forests, two for grasslands, and two for croplands (Krinner et al., 2005).

In the trunk version of ORCHIDEE, soil carbon is based on the CENTURY model following Parton et al. (1988). Accordingly, soil carbon is divided in two litter pools (metabolic and structural) and three soil organic carbon (SOC) pools (slow, active, and passive) based on SOC stability, each with different turnover rates. The turnover rate of each pool is controlled by temperature, moisture, and clay content and results in carbon fluxes from the litter to the SOC as well as from and between the three SOC pools. The fraction of the decomposed carbon being transferred from one pool to another is prescribed using parameters based on Parton et al. (1988; Table 1) and the rest is lost to the atmosphere as heterotrophic respiration. The vertical distribution of SOC with particular dynamics at each depth is not considered and losses of soil carbon by dissolution and transport are not represented in the model (Fig. 1).

ORCHIDEE-SOM upgrades the trunk version of ORCHIDEE to simulate carbon dynamics in the soil column down to $2 \mathrm{~m}$ of depth, partitioned in 11 layers following the same scheme as in the hydrological module ORC11 (Campoy et al., 2013; Guimberteau et al., 2014). ORCHIDEESOM mechanistically models the concentration of DOC in each soil layer and its transport between layers. Moreover, the upgraded module links SOC decomposition with the amount of fresh organic matter as a way of accounting for the priming effect (Guenet et al., 2018).

In short, ORCHIDEE-SOM represents four litter pools (metabolic aboveground litter, metabolic belowground litter, structural aboveground litter, and structural belowground litter) and three SOC pools based on their turnover rate (active, slow, and passive). Two new pools were added to represent the DOC defined by their turnover rate: the labile and the stable DOC, with a high and low turnover rate, respectively. Each pool may be in the soil solution or adsorbed on the mineral matrix. The products of litter and SOC decomposition go to free DOC, which in turn is decomposed following a firstorder kinetics equation (e.g., Kalbitz et al., 2003; Qualls and Haines, 1992b). One part of the decomposed DOC goes back to SOC pools according to a fixed microbial carbon use efficiency $\left(\mathrm{CUE}_{\mathrm{DOC}}\right)$ parameter, and the other part is converted into $\mathrm{CO}_{2}$ and contributes to heterotrophic respiration. The free DOC can then be adsorbed to soil minerals or remain in solution following an equilibrium distribution coefficient ( $K_{\mathrm{D}}$; Nodvin et al., 1986), which depends on soil properties (clay and $\mathrm{pH}$ ). Adsorbed DOC is assumed to be protected and thus is neither decomposed nor transported within the soil column. Free DOC is subject to transport with the water flux between layers calculated by the soil hydrological module of ORCHIDEE, i.e., by advection. Also, SOC and DOC are subject to diffusion that is represented using the second Fick's law of diffusion. All the described processes occur within each soil layer. At the end of every time step, the flux of DOC (expressed in $\mathrm{g} \mathrm{C}^{-2} \mathrm{day}^{-1}$ ) leaving the soil with runoff (upper layer) and drainage (bottom layer) is calculated by multiplying DOC concentrations in the solution with the runoff and drainage flux calculated by the hydrological module ORC11 (Fig. 1).

This section presents the new ORCHIDEE-SOM formulations in more detail, focusing first on the vertical discretization scheme, followed by the newly implemented biological 
Table 1. List of parameters of ORCHIDEE-SOM (the name used in the model is between brackets), with their description, value, units, and the parameterization used for each parameter.

\begin{tabular}{|c|c|c|c|c|}
\hline Parameter & Description & Value & Units & Parameterization \\
\hline \multicolumn{5}{|c|}{ Fixed } \\
\hline $\begin{array}{l}\text { Z_litter } \\
\left(z \_ \text {litter }\right)\end{array}$ & Thickness litter above & 10 & $\mathrm{~mm}$ & Assumed \\
\hline \multicolumn{5}{|c|}{ Soil carbon parameters } \\
\hline $\begin{array}{l}\text { frac_carb_ap } \\
(\text { frac_carb_ap) }\end{array}$ & $\begin{array}{l}\text { Fraction of the active pool going into } \\
\text { the passive pool }\end{array}$ & 0.004 & - & Parameterization based on Parton et al. (1987) \\
\hline $\begin{array}{l}\text { frac_carb_sa } \\
(\text { frac_carb_sa) }\end{array}$ & $\begin{array}{l}\text { Fraction of the slow pool going into the } \\
\text { active pool }\end{array}$ & 0.93 & - & Parameterization based on Parton et al. (1987) \\
\hline $\begin{array}{l}\text { frac_carb_sp } \\
(\text { frac_carb_sp) }\end{array}$ & $\begin{array}{l}\text { Fraction of the slow pool going into the } \\
\text { passive pool }\end{array}$ & 0.07 & - & Parameterization based on Parton et al. (1987) \\
\hline $\begin{array}{l}\text { frac_carb_pa } \\
(\text { frac_carb_pa) }\end{array}$ & $\begin{array}{l}\text { Fraction of the passive pool going into } \\
\text { the active pool }\end{array}$ & 1 & - & Parameterization based on Parton et al. (1987) \\
\hline $\begin{array}{l}\text { frac_carb_ps } \\
(\text { frac_carb_ps) }\end{array}$ & $\begin{array}{l}\text { Fraction of the passive pool going into } \\
\text { the slow pool }\end{array}$ & 0 & - & Parameterization based on Parton et al. (1987) \\
\hline $\begin{array}{l}\text { active_to_pass_clay_frac } \\
\text { (active_to_pass_clay_frac) }\end{array}$ & & 0.68 & & Parton et al. (1987) \\
\hline $\begin{array}{l}\text { carbon_tau active } \\
\text { (carbon_tau_iactive) }\end{array}$ & Turnover times in carbon pools & 1 & years & This study \\
\hline $\begin{array}{l}\text { carbon_tau slow } \\
\text { (carbon_tau_islow) }\end{array}$ & Turnover times in carbon pools & 6.0 & years & This study \\
\hline $\begin{array}{l}\text { carbon_tau passive } \\
\text { (carbon_tau_ipassive) }\end{array}$ & Turnover times in carbon pools & 462.0 & years & This study \\
\hline $\begin{array}{l}\text { priming_param (c) active } \\
\text { (priming_param_iactive) }\end{array}$ & $\begin{array}{l}\text { Priming parameter for mineralization } \\
\text { active }\end{array}$ & 493.66 & & Guenet et al. (2016) \\
\hline $\begin{array}{l}\text { priming_param (c) slow } \\
\text { (priming_param_islow) }\end{array}$ & $\begin{array}{l}\text { Priming parameter for mineralization } \\
\text { slow }\end{array}$ & 194.03 & & Guenet et al. (2016) \\
\hline $\begin{array}{l}\text { priming_param (c) passive } \\
\text { (priming_param_ipassive) }\end{array}$ & $\begin{array}{l}\text { Priming parameter for mineralization } \\
\text { passive }\end{array}$ & 136.54 & & Guenet et al. (2016) \\
\hline $\begin{array}{l}\text { FLUX_TOT_COEFF } \\
\text { (flux_tot_coeff) }\end{array}$ & $\begin{array}{l}\text { Coefficient modifying the fluxes ( } 1.2 \\
\text { and } 1.4 \text { increase decomposition due to } \\
\text { tillage, } 0.75 \text { modify the flux depending } \\
\text { on clay content) }\end{array}$ & $1.2,1.4,0.75$ & days & $\begin{array}{l}\text { Gervois et al. (2008) for } 1.2 \text { and } 1.4 \text {; Parton } \\
\text { et al. (1987) for } 0.75\end{array}$ \\
\hline $\begin{array}{l}\mathrm{D} \\
(\text { Dif })\end{array}$ & $\begin{array}{l}\text { Diffusion coefficient used for bioturba- } \\
\text { tion litter and soil carbon }\end{array}$ & $2.74 \times 10^{-7}$ & $\mathrm{~m}^{2}$ day $^{-1}$ & Koven et al. (2013) \\
\hline \multicolumn{5}{|c|}{ DOC parameters } \\
\hline $\begin{array}{l}\text { DOC_tau_labile } \\
\left(D O C \_T A U \_L A B I L E\right)\end{array}$ & Turnover time of labile DOC & 1.3 & days & $\begin{array}{l}\text { Value within the range found in the literature for } \\
\text { fast pool of DOC } \\
\text { (Boddy et al., 2008; Kalbitz et al., 2003; Qualls } \\
\text { and Haines, 1992b; Turgeon, 2008) }\end{array}$ \\
\hline $\begin{array}{l}\text { DOC_tau_stable } \\
\left(D O C \_T A U \_S T A B L E\right)\end{array}$ & Turnover time of stable DOC & $\begin{array}{l}60.4 \\
1.3^{\mathrm{a}}\end{array}$ & days & $\begin{array}{l}\text { Value within the range found in the literature } \\
\text { (Boddy et al., 2007, 2008; Kalbitz et al., 2003; } \\
\text { Qualls and Haines, 1992b; Turgeon, 2008) }\end{array}$ \\
\hline $\begin{array}{l}\text { D_DOC } \\
\left(D \_D O C\right)\end{array}$ & $\begin{array}{l}\text { Diffusion coefficient used for DOC dif- } \\
\text { fusion }\end{array}$ & $1.0627 \times 10^{-5}$ & $\mathrm{~m}^{2}$ day $^{-1}$ & Burdige et al. (1999) in Ota et al. (2013) \\
\hline $\begin{array}{l}\text { CUE }_{\mathrm{DOC}} \\
(C U E)\end{array}$ & $\begin{array}{l}\text { Percentage of DOC decomposed that } \\
\text { releases to } \mathrm{CO}_{2}\end{array}$ & $\begin{array}{l}\text { PFT-dependent } \\
\text { value: range } \\
0.3-0.55\end{array}$ & - & $\begin{array}{l}\text { Manzoni et al. (2012) } \\
\text { Sinsabaugh et al. (2013) }\end{array}$ \\
\hline $\begin{array}{l}K_{\mathrm{D}} \\
\left(k d \_a d s\right)\end{array}$ & $\begin{array}{l}\text { Distribution coefficient of adsorbed } \\
\text { DOC }\end{array}$ & $\begin{array}{l}\text { Statistical } \\
\text { relationship } \\
\text { (Eq. 15) }\end{array}$ & $\begin{array}{l}\mathrm{m}^{3} \text { water } \\
\mathrm{kg}^{-1} \text { soil }\end{array}$ & $\begin{array}{l}\text { Statistical relationship based on Kaiser } \\
\text { et al. (1996) data }\end{array}$ \\
\hline
\end{tabular}

a The default DOC_tau_stable value in the model is 60.4 days, but DOC_tau_stable was adjusted to 1.3 days for the runs in the Hainich forest and the Carlow grassland and cropland. 

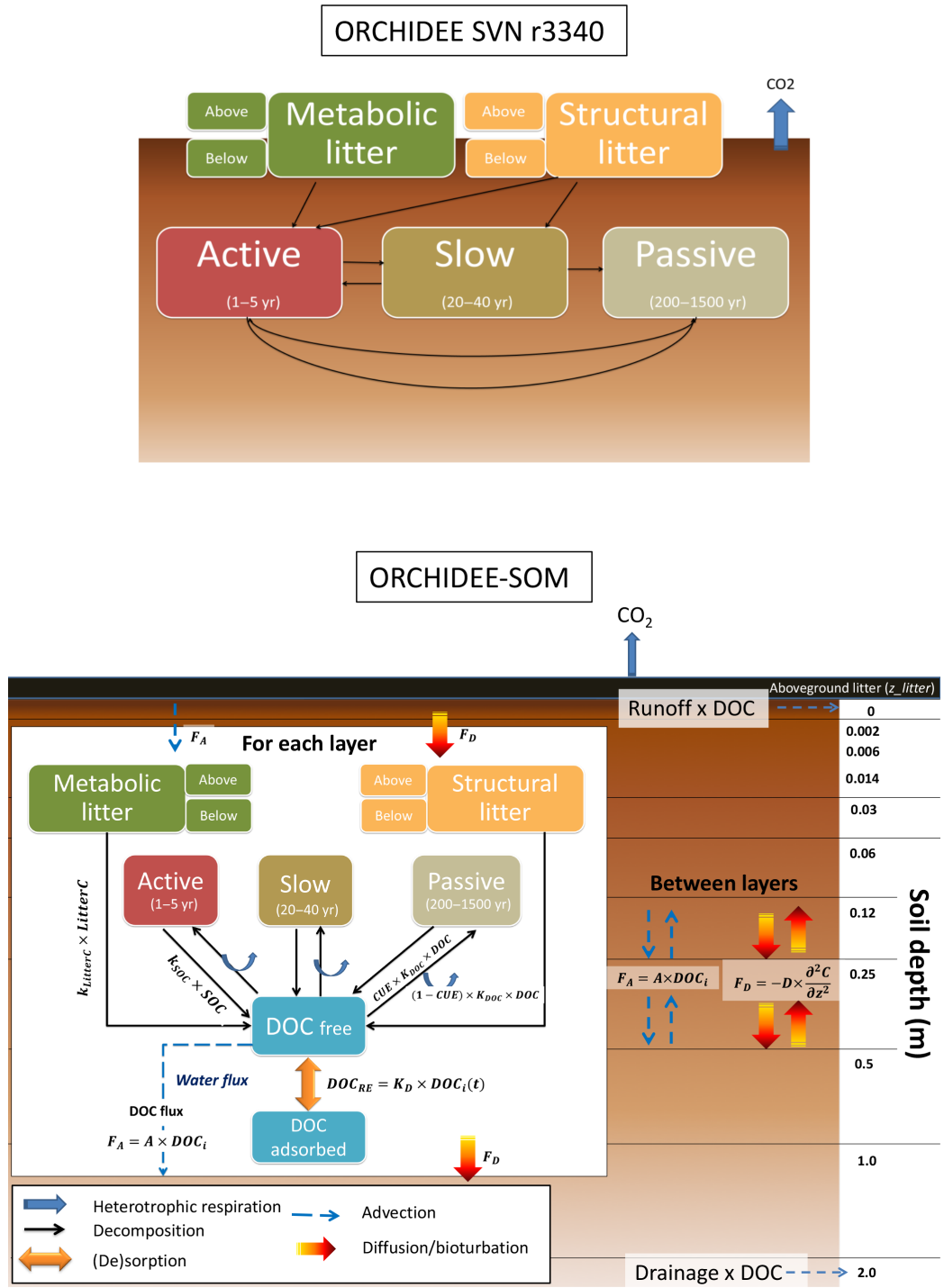

Figure 1. Overview of the revised version of ORCHIDEE-SOM presented here (lower panel) compared to the soil module in the trunk version of ORCHIDEE SVN r3340 (upper panel). The white box represents pools, fluxes, and major processes occurring in each of the 11 soil layers. The equations used for the processes occurring within and between layers are represented (see text for details).

and physical processes affecting soil carbon (i.e., decomposition, sorption of DOC, advection, and diffusion) and, finally, the model parameterization and evaluation exercise are described.

\subsection{Vertical discretization of the soil carbon module}

For mathematical reasons, ORCHIDEE SVN r3340 has two different discretized schemes for soil physics: one for energy and other for hydrology. Since ORCHIDEE-SOM requires the transport of water between layers and drainage for the calculation of DOC concentrations and fluxes, we adopted the discretization used for the soil hydrology scheme whose performance has already been tested against tropical (Guimberteau et al., 2014), boreal (Gouttevin et al.,
2012), and temperate datasets (Campoy et al., 2013). Therefore, ORCHIDEE-SOM represents a $2 \mathrm{~m}$ soil column with 11 discrete layers of geometrically increasing thicknesses with depth. This kind of geometric configuration is used in most LSMs describing the vertical soil water fluxes based on the Richards equation, such as ORCHIDEE (Campoy et al., 2013). More information on the hydrological formulation of ORCHIDEE is given in Sect. 2.2.3.

The midpoint depths (in meters from the surface) of the layers in the discretized soil column are 0.00098, 0.00391, $0.00978,0.02151,0.04497,0.09189,0.18573,0.37341$, 0.74878 , and 1.49951, respectively. The first layers in the soil hydrology discretization scheme are thinner $(1 \mathrm{~mm})$ than needed in terms of biological and pedogenic process representation. Nevertheless, we decided to integrate the 11-layer 
scheme for technical reasons: it simplifies the coding and the understanding of the code for the users. At every time step, each soil layer is updated with all the sources and sinks of DOC due to the represented biological and physical processes.

The new 11-layer scheme applies to the soil carbon in the mineral soil and for the belowground litter (see Sect. 2.2.1). However, the aboveground litter layer in ORCHIDEE is dimensionless, which means that processes of production and decomposition of aboveground litter occur independently of the litter layer thickness in the model. In ORCHIDEE-SOM, a new parameter to define the thickness of the aboveground litter layer (z_litter), assumed as constant over time, has been added to allow for the calculation of aboveground litter diffusion into the mineral soil (Table 1).

A final remark is that ORCHIDEE-SOM is a land surface model designed for global simulations and currently there is no information on actual soil depths globally. Therefore, we fixed a global maximum soil depth, as is normally done in soil modules within land surface models (e.g., Koven et al., 2013). In our case, we assume that soil $C$ cycling takes place to $2 \mathrm{~m}$ of depth based on the discretization used for the soil hydrology scheme.

\subsection{Biological and physical processes affecting SOC and DOC}

\subsubsection{Litter, SOC, and DOC dynamics within each soil layer}

In ORCHIDEE-SOM, litter is defined by two pools called metabolic and structural with high and low turnover rates, respectively. Aboveground and belowground litter are separated pools. While belowground litter is discretized over the 11-layer scheme down to $2 \mathrm{~m}$, the aboveground litter layer is simply defined by a fixed thickness parameter (Table 1). The litter is distributed belowground following an exponential root profile with a different root density profile parameter $(\alpha)$ for each PFT.

$\mathrm{rp}=1 /\left(1-e^{(-\operatorname{depth} / \alpha)}\right)$,

with rp being the root profile, "depth" the maximum depth of the model (fixed to $2 \mathrm{~m}$ ), and $\alpha$ a PFT parameter dependent (in meters). Litter (LitterC) decomposition for each pool $i$ (aboveground metabolic, aboveground structural, belowground metabolic, and belowground structural) is described by first-order kinetics (Eq. 2):

$$
\begin{aligned}
\frac{\partial \operatorname{LitterC}_{i, z}}{\partial t} & =I(t)_{i, z}-k_{\mathrm{LitterCi}} \\
& \times \operatorname{LitterC}_{i, z}(t) \times \theta(t) \times \tau(t),
\end{aligned}
$$

with $I$ being the carbon input coming from deceased plant tissues in $\mathrm{gC} \mathrm{m}^{-2}$ ground days ${ }^{-1}$ and $k_{\mathrm{LitterC}}$ the litter turnover rate constants in days ${ }^{-1}$, which are fixed and similar to the rates used for SOC in ORCHIDEE SVN r3340 (Table 1). The litter decomposition is affected by two rate modifiers, $\theta$ and $\tau$, to take into account the effect of moisture and temperature, respectively:

$$
\begin{aligned}
& \theta=\max \left(0.25, \min \left(1,1.1 \times M^{2}+2.4 \times M+0.29\right)\right), \\
& \tau=\min \left(1, e^{(0.69 \times(T-303.15) / 10)}\right),
\end{aligned}
$$

with $M$ and $T$ being the soil moisture $\left(\mathrm{m}^{3} \mathrm{~m}^{-3}\right)$ and the temperature $(\mathrm{K})$ of the layer considered. For the aboveground litter (dimensionless), averaged moisture and temperature over the four first layers are used to calculate the rate modifiers given by Eqs. (3) and (4).

The SOC is defined by three pools, so-called active, slow, and passive, with different turnover rates. The SOC decomposition is based on Guenet et al. (2013):

$$
\begin{aligned}
\frac{\partial \operatorname{SOC}_{i, z}}{\partial t}= & \operatorname{DOC}_{\text {Recycled, } i, j}(t)-k_{\mathrm{SOC}, i} \times\left(1-e^{-c \times \operatorname{LOC}_{z}(t)}\right) \\
& \times \operatorname{SOC}(t)_{i, z} \times \theta(t) \times \tau(t)
\end{aligned}
$$

with $\mathrm{DOC}_{\text {recycled }}$ being the non-respired DOC (defined below) that is redistributed into the pool $i$ considered for each soil layer $z$ coming in $\mathrm{g} \mathrm{C}^{-2}$ days $^{-1}, k_{\mathrm{SOC}}$ an SOC turnover rate constant (days ${ }^{-1}$ ), and LOC the stock of labile organic $\mathrm{C}$ defined as the sum of the $\mathrm{C}$ pools with a higher turnover rate than the pool considered within each soil layer $z$. This means that for the active carbon pool LOC is the litter and DOC, but for the slow carbon pool LOC is the sum of the litter, DOC, and active SOC pools. For the passive carbon pool, LOC is the sum of litter, DOC, active, and slow SOC pools. Finally, $c$ is a parameter controlling the impact of the LOC pool on the SOC mineralization rate, i.e., the priming effect (Guenet et al., 2016; Table 1). The decomposition of the active SOC pool is further modified by a clay modifier, which considers the SOC decomposition to decrease when increasing the clay content:

$\gamma=1-0.75 \times$ clay.

In reality, DOC is produced from soil microbial biomass, litter, soil organic carbon, root exudates, and desorption from minerals. In ORCHIDEE-SOM, all the products of decomposition from litter and SOC go to free DOC based on the assumption that the soluble state is a prerequisite for the uptake and degradation of organic matter by microorganisms (Marschner and Kalbitz, 2003). We assumed that root exudates are represented within the decomposed belowground metabolic litter and that the root-derived material comes within the products of decomposition of the belowground structural litter. In ORCHIDEE-SOM, like in most of the 
current global-scale LSMs, soil microbial biomass is not explicitly represented (Schmidt et al., 2011; Todd-Brown et al., 2013). Instead, we assumed that all DOC is taken up by microorganisms, which then use a certain portion of organic $\mathrm{C}$ for respiration and the rest for growth (controlled by the microbial carbon use efficiency), which eventually ends up as dead microbial biomass in the SOC pools (Gleixner, 2013).

In the model, DOC is represented using two pools that are defined by their turnover rates: the labile DOC pool with a high turnover rate and the stable DOC pool with a lower turnover rate (Table 1; Turgeon, 2008). The labile pool corresponds to the DOC coming from litter and active carbon, while the stable pool corresponds to the DOC coming from slow and passive carbon. The DOC pools in the model can be free in the soil solution or adsorbed to the soil minerals. To avoid extremely high and unrealistic DOC concentrations in the first very thin soil layer, the DOC coming from aboveground litter decomposition is redistributed among the first five soil layers, which represent approximately the first $5 \mathrm{~cm}$ of soil. Only the free DOC is decomposed in the model, following the first-order kinetics equation (Eq. 7), a classical approach to describe DOC decomposition (Kalbitz et al., 2003). Therefore, the change in DOC for each pool $i$ due to biological activity at each layer and every time step is described as

$$
\begin{aligned}
\frac{\partial \mathrm{DOC}_{i, z}}{\partial t} & =I_{\text {litter }}(t)_{i, z}+I_{\mathrm{SOC}}(t)_{i, z}-k_{\mathrm{DOC}, i} \\
& \times \operatorname{DOC}(t)_{i, z},
\end{aligned}
$$

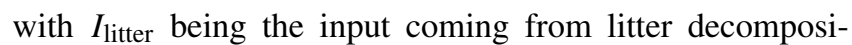
tion and $I_{\mathrm{SOC}}$ the input coming from SOC decomposition (corresponding to the second term of Eqs. 2 and 5, respectively) in $\mathrm{g} \mathrm{C} \mathrm{m}^{-2}$ ground days ${ }^{-1} ; k_{\mathrm{DOC}}$ is a parameter representing the turnover rate constant of free DOC pool $i$ (labile and stable) in days ${ }^{-1}$, which corresponds to the inverse of the DOC_tau_labile or DOC_tau_stable parameters in ORCHIDEE-SOM (Table 1). The decomposed DOC (second term of Eq. 7) is partially respired and partially redistributed in the SOC pools, the fraction of respired DOC (RespDOC) in $\mathrm{g} \mathrm{C} \mathrm{m}^{-2}$ day $^{-1}$ being controlled by the carbon use efficiency $\left(\mathrm{CUE}_{\mathrm{DOC}}\right)$ parameter, which remains constant for all paths from DOC to SOC pools (Table 1, Eq. 8):

$\operatorname{Resp}_{\mathrm{DOC}, i, z}(t)=\left(1-\mathrm{CUE}_{\mathrm{DOC}}\right) \times k_{\mathrm{DOC}, i} \times \mathrm{DOC}(t)_{i, z}$.

The non-respired, recycled $\mathrm{DOC}$ (DOC $\left.\mathrm{Decycled}_{\mathrm{R}}\right)$ coming from active, slow, and passive SOC pools is redistributed in the different SOC pools following the same parameters as in the CENTURY model (Guenet et al., 2016; Parton et al., 1988):

$$
\begin{aligned}
\text { DOC }_{\text {Recycled, } \mathrm{i}, \mathrm{j}}(t)= & f r a \_c a r b \_i j \times \mathrm{CUE}_{\mathrm{DOC}} \times K_{\mathrm{DOC}, \mathrm{i}} \\
& \times \mathrm{DOC}(t)_{i, z},
\end{aligned}
$$

with DOC Recycled, $i, j$ being the DOC flux going back from pool $i$ to pool $j$ and frac_carb_ij the prescribed fraction of carbon from pool $i$ to $j$ (Table 1).

\subsubsection{DOC sorption to soil minerals}

DOC retention in mineral soils is largely driven by abiotic processes of adsorption and desorption. Most of the DOC models commonly represent adsorption using the simple initial mass (IM) linear isotherm (Eq. 10; Neff and Asner, 2001; Wu et al., 2014) or using a first-order kinetic reaction to represent a linear adsorption (Laine-Kaulio et al., 2014; Michalzik et al., 2003):

$\mathrm{DOC}_{\mathrm{RE}}=m \times \mathrm{DOC}_{i}-b$,

with $\mathrm{DOC}_{\mathrm{RE}}$ being the amount of DOC desorbed (negative value) or adsorbed (positive value), $m$ a regression coefficient similar to the partitioning coefficient, $\mathrm{DOC}_{i}$ the initial concentration of free DOC in solution, and $b$ the intercept (the desorption parameter) in $\mathrm{g} \mathrm{kg}^{-1}$ soil.

In principle, the IM and linear approaches are expressions of a simple partitioning process in which the tendency of the soil to adsorb DOC is described by an equilibrium partition coefficient $\left(K_{\mathrm{D}}\right)$. Hence, $K_{\mathrm{D}}$ is defined as a measure of the affinity of the substances for the soil when the reactive substance present in the soil (DOC in our case) is assumed to be insignificant. The equilibrium partition coefficient can be related to the regression coefficient $m$ in the IM isotherm following Nodvin et al. (1986) by Eq. (11):

$K_{\mathrm{D}}=\frac{m}{1-m} \times \frac{(\text { volume of solution })}{(\text { mass of soil })}$,

where $K_{\mathrm{D}}\left(\mathrm{m}^{3} \mathrm{~kg}^{-1}\right.$ soil) represents the equilibrium distribution between the adsorbed and free dissolved organic carbon and will thus vary depending on the adsorption capacity of the soil profile.

ORCHIDEE-SOM assumes that adsorption-desorption occurs due to the deviation between the actual concentration of adsorbed DOC and the equilibrium adsorbed DOC defined by $K_{\mathrm{D}}$. Therefore, the DOC adsorption in soil minerals in ORCHIDEE-SOM is formulated as follows.

$$
\begin{aligned}
& \operatorname{DOC}_{\mathrm{RE}-\mathrm{EQ}}=K_{\mathrm{D}} \times \mathrm{DOC}_{T}(t) \\
& \frac{\partial \mathrm{DOC}_{i}}{\partial t}=\mathrm{DOC}_{i}(t)-\left(\mathrm{DOC}_{\mathrm{RE}-\mathrm{EQ}}(t)-\operatorname{DOCad}_{i}(t)\right) \\
& \frac{\partial \mathrm{DOCad}_{i}}{\partial t}=\operatorname{DOCad}_{i}(t) \\
& \quad+\left(\operatorname{DOC}_{\mathrm{RE}-\mathrm{EQ}}(t)-\operatorname{DOCad}_{i}(t)\right)
\end{aligned}
$$

In Eq. (12), DOC $\mathrm{RE}_{\mathrm{EQ}}$ is the amount of adsorbed DOC in equilibrium according to the partition coefficient $K_{\mathrm{D}}$ (unitless). $\mathrm{DOC}_{T}(t), \mathrm{DOC}_{i}(t)$, and $\mathrm{DOCad}_{i}(t)$ are the total DOC (the sum of free and adsorbed DOC), the free DOC and the adsorbed DOC for each pool (labile and stable) in $\mathrm{g} \mathrm{C} \mathrm{m}^{-2}$ ground, respectively.

This approach assumes that the free DOC produced at every time step of the model $(30 \mathrm{~min})$ is immediately distributed between the adsorbed and free pools to reach equilib- 
rium, which is in agreement with studies showing that sorption occurs rapidly, within seconds to minutes (Kothawala et al., 2008; Qualls and Haines, 1992a).

\section{Dependence of the sorption distribution coefficient on soil properties}

The adsorption characteristics of soils have previously been related to several soil properties. For instance, the desorption parameter $(b)$ of the IM isotherm (Eq. 10) has been related to the organic carbon content in the soil profile, whereas the partition coefficient $(m)$ was related to oxalate-extractable aluminium $\left(\mathrm{Al}_{\mathrm{o}}\right)$, dithionite-extractable iron $\left(\mathrm{Fe}_{\mathrm{d}}\right)$, and organic carbon content (Kaiser et al., 1996). Also, the maximum adsorption capacity of a soil was found to correlate with $\mathrm{Fe}$ and $\mathrm{Al}$ in soil (Kothawala et al., 2008). Despite the accepted importance of $\mathrm{Al}$ and $\mathrm{Fe}$ in controlling DOC dynamics in soils (Camino-Serrano et al., 2014), these variables are not globally available and hence not included in the land surface model ORCHIDEE. Therefore, in order to produce a statistical model that predicts the $K_{\mathrm{D}}$ parameter as a soilcondition-dependent variable, we focused on other soil parameters available within ORCHIDEE that correlated with the $K_{\mathrm{D}}$ coefficient of DOC sorption in soils and are indicative of $\mathrm{Al}$ and $\mathrm{Fe}$ in the soil, which are clay, organic carbon (OC), and pH (e.g., Jardine et al., 1989; Kaiser et al., 1996; Moore et al., 1992).

We calculated the distribution coefficient $K_{\mathrm{D}}$ from the IM isotherm partition coefficient $(m)$ measured in batch experiments on 34 European soil profiles (Kaiser et al., 1996), according to Eq. (11), and built an empirical model that related $K_{\mathrm{D}}$ to soil depth, clay, and $\mathrm{pH}$. We selected the best model by means of stepwise regressions. The distribution of the residuals was tested and models whose residuals were not normally distributed were discarded. The selected model included only clay and soil $\mathrm{pH}$ as explanatory variables and explained $25 \%$ of the variability in $K_{\mathrm{D}}$ (adjusted $R^{2}=0.25$; Fig. $\mathrm{S} 1$ in the Supplement; Eq. 15):

$K_{\mathrm{D}}=0.001226-0.000212 \cdot \mathrm{pH}+0.00374 \cdot$ Clay

By using this relationship, the effects of soil texture and $\mathrm{pH}$ on the adsorption capacity of the soil are represented empirically in the model.

\subsubsection{Vertical fluxes of SOC and DOC}

ORCHIDEE-SOM assumes that SOC and DOC move along the soil profile as a result of three processes: bioturbation results in vertical fluxes of SOC, and diffusion and advection produce vertical fluxes of DOC.

\section{Diffusion}

In general, bioturbation, which is defined as the transport of plant debris and soil organic matter by soil fauna, causes homogenization of soil properties, i.e., the net transport of soil constituents proportional to the concentration gradient. Therefore, the effects of bioturbation on the distribution of soil properties is commonly represented in models as a diffusion process using Fick's diffusion equation (e.g., Braakhekke et al., 2011; Elzein and Balesdent, 1995; O'Brien and Stout, 1978; Wynn et al., 2005). However, some conditions must be respected to use Fick's law for bioturbation. (1) The time between mixing events must be short compared to other processes. (2) The size of each layer must be small compared to the total depth of the profile, and (3) the mixing should be isotropic (bottom-up and top-down; Braakhekke et al., 2011). If these conditions are fulfilled, bioturbation can lead to diffusive behavior of soil constituents and can be represented by Fick's diffusion law (Boudreau, 1986). On small spatial scales, bioturbation may not meet these criteria, but on sufficiently large spatial scales, the assumption of diffusive behavior is reasonable (Braakhekke et al., 2011). Hence, we assume that bioturbation can be modeled as a diffusion process on the global scale, for which ORCHIDEE-SOM is designed.

Therefore, in ORCHIDEE-SOM, we represented bioturbation with a diffusion equation based on Fick's second law (Eq. 16):

$$
F_{\mathrm{D}}=-D \times \frac{\partial^{2} C}{\partial z^{2}},
$$

where $F_{\mathrm{D}}$ is the flux of $\mathrm{C}$ transported by diffusion in $\mathrm{g} \mathrm{Cm}^{-3}$ soil day ${ }^{-1},-D$ the diffusion coefficient $\left(\mathrm{m}^{2} \mathrm{day}^{-1}\right)$, and $C$ the amount of carbon in the pool subject to transport $\left(\mathrm{g} \mathrm{C} \mathrm{m}^{-3}\right.$ soil). In ORCHIDEE-SOM, bioturbation represented as diffusion applies to the SOC pools, and the belowground litter and the diffusion coefficient are assumed to be constant across the soil profile in ORCHIDEE-SOM (Table 1).

DOC may also be transported by diffusion following Eq. (16), but with a different diffusion coefficient $\left(D \_D O C\right.$; Table 1). Unlike for SOC and belowground litter, the diffusion of DOC is not due to bioturbation processes, but is a representation of DOC movement due to actual diffusion; that is, movements of molecules due to concentration gradients. For this, we assume that the water distribution is continuous along the soil column (i.e., there are no dry places), which is an assumption that does not always hold true in nature where DOC is actually transported through preferential flow pathways determined by wormholes and other biogalleries.

\section{Advection}

Like most models, ORCHIDEE-SOM represents the transport of carbon with the liquid phase (only DOC in our case) by means of advection (e.g., Braakhekke et al., 2011; Futter et al., 2007). The calculation of advection fluxes in ORCHIDEE-SOM relies on the flux of water between soil layers as calculated by the soil hydrology module ORC11, which is briefly described hereafter. 
The soil hydrology module is based on the $2 \mathrm{~m}$ vertical discretization of the soil column (see Sect. 2.1). A physically based description of the unsaturated water flow was introduced in ORCHIDEE by de Rosnay et al. (2002). Soil water flux calculations rely on a one-dimensional Fokker-Planck equation combining the mass and momentum conservation equations using volumetric water content as a state variable (Campoy et al., 2013). Due to the large scale on which ORCHIDEE is applied, the lateral fluxes between adjacent grid cells are neglected. Also, all variables are assumed to be horizontally homogeneous. The flux field $q$ along the soil profile comes from the equation of motion known as the Darcy (1856) equation in the saturated zone and extended to unsaturated conditions by Buckingham (1907):

$q(z, t)=-D(\theta(z, t)) \frac{\partial \theta(z, t)}{\partial z}+K(\theta(z, t))$.

In this equation, $z$ is the depth $(\mathrm{m})$ below the soil surface, $t$ (s) is the time, $K(\theta)\left(\mathrm{m} \mathrm{s}^{-1}\right)$ is the hydraulic conductivity, and $D(\theta)\left(\mathrm{m}^{2} \mathrm{~s}^{-1}\right)$ is the diffusivity.

The soil hydrological module counts the following boundary conditions at the soil surface and at the bottom layer. First, throughfall (precipitation minus interception loss) is partitioned between soil evaporation, infiltration into the soil and surface runoff that is assumed to be produced by infiltration excess. The infiltration rate depends on precipitation rates, local slope, and vegetation and is limited by the hydraulic conductivity of the soil, which defines a Hortonian surface runoff (d'Orgeval et al., 2008; Lauerwald et al., 2017). Soil evaporation is calculated assuming that it can proceed at the potential rate unless water becomes limiting. Second, ORCHIDEE assumes conditions of free gravitational drainage at the soil bottom. This boundary condition implies that soil moisture is constant below the lower node, which is not always the case in nature. In particular, when a shallow water table is present, water saturation within the soil column cannot be modeled within ORCHIDEE. More information on the calculation of the water flux, runoff, and drainage can be found in Campoy et al. (2013).

The transport of DOC within the liquid phase is assumed to occur due to advection flux and is modeled as the flow of water calculated by the hydrology module multiplied by the concentration of DOC at each layer according to Eq. (18) (Futter et al., 2007):

$F_{\mathrm{A}}=A \times \mathrm{DOC}_{i}$,

with $F_{\mathrm{A}}$ the advection flux of free DOC in $\mathrm{g} \mathrm{C} \mathrm{m}^{-2} 30 \mathrm{~min}^{-1}$, $A$ the flux of water calculated by the hydrological module in $\mathrm{kg} \mathrm{m}^{-2} 30 \mathrm{~min}^{-1}$, and $\mathrm{DOC}_{i}$ the concentration of DOC free in solution in pool $i$ in $\mathrm{g} \mathrm{C} \mathrm{m}^{-3}$ water.

At every time step, DOC in each layer is updated with the DOC fluxes entering and leaving the soil layer. The final DOC concentration in the last and the first five layers is multiplied by drainage and runoff, respectively, to calculate the amount of DOC leaving the system $\left(\mathrm{g} \mathrm{C}^{-2}\right.$ ground).

\subsection{Model parameterization and evaluation}

\subsubsection{Sites description}

Four European sites with available data on soil DOC concentrations and SOC stocks were selected for the validation of ORCHIDEE-SOM. The four sites correspond to four different PFTs: Brasschaat, a coniferous forest, Hainich, a deciduous forest, and two experimental sites in Carlow: the so-called "Lawn Field", a grassland, and the "Pump Field", a cropland (hereafter referred to as Carlow grassland and Carlow cropland, respectively). Brasschaat forest (Belgium; $51^{\circ} 18^{\prime} \mathrm{N}, 4^{\circ} 31^{\prime} \mathrm{E}$ ) is a Scots pine (Pinus sylvestris) forest growing in a sandy soil classified as Albic Hypoluvic Arenosol (Gielen et al., 2011; Janssens et al., 1999). Hainich forest (Germany; $51^{\circ} 4^{\prime} \mathrm{N}, 10^{\circ} 27^{\prime} \mathrm{E}$ ) is a forest with beech (Fagus sylvatica) as the dominant species growing in a clayey soil classified as Eutric Cambisol (Kutsch et al., 2010; Schrumpf et al., 2013). In Carlow grassland (Ireland; $52^{\circ} 52^{\prime} \mathrm{N}, 6^{\circ} 54^{\prime} \mathrm{W}$ ) a mixture of $\sim 70 \%$ perennial ryegrass and $30 \%$ white clover was sown in a loamy soil classified as Calcic Luvisol (Walmsley, 2009). Finally, Carlow cropland (Ireland; $52^{\circ} 51^{\prime} \mathrm{N}, 6^{\circ} 55^{\prime} \mathrm{W}$ ) is an arable site that has been under crop rotation for the last 45 years and under spring barley cultivation from 2000 to the present. The soil in Carlow cropland is classified as Eutric Cambisol (Schrumpf et al., 2013; Walmsley et al., 2011). Therefore, these four sites cover a wide range of vegetation cover and soil properties (from acidic to circumneutral soils and from sandy to clayey soils; Table 2).

At the four sites, measurements of DOC concentrations were available for at least 1 year (Table 2). DOC concentrations were typically measured fortnightly, except for periods when sites could not be reached or when soils were too dry to extract water. DOC concentrations were available at more than one soil horizon for all sites, except for Carlow cropland. In Carlow grassland, there were two sampling positions (Box 1 and Box 2) located next to each other but substantially differing in some soil properties, like texture and soil water content (Walmsley, 2009). More detailed information about the sampling and analysis for DOC concentrations can be found in Gielen et al. (2011) and Kindler et al. (2011).

SOC concentrations along the soil profile were measured at Brasschaat, Hainich, and Carlow cropland by dry combustion (TC analyzer; Schrumpf et al., 2013). At Hainich and Carlow, the concentration of inorganic $\mathrm{C}$ was determined by removing all organic carbon at a temperature of $450{ }^{\circ} \mathrm{C}$ for $16 \mathrm{~h}$, followed by $\mathrm{C}$ analyses similar to total $\mathrm{C}$ by dry combustion in an elemental analyzer (VarioMax, Hanau, Germany). Organic $\mathrm{C}$ concentrations were determined by the difference between total and inorganic C. SOC contents in Carlow grassland were indirectly estimated by loss of ignition (LOI) at $500^{\circ} \mathrm{C}$. The LOI values were multiplied by a conversion factor of 0.55 (Hoogsteen et al., 2015) to obtain the SOC concentration. SOC stocks were then calculated at each 
Table 2. Characteristics of the four sites used for the model validation.

\begin{tabular}{|c|c|c|c|c|}
\hline \multicolumn{5}{|l|}{ Site characteristics } \\
\hline Site & Brasschaat & Hainich & Carlow & Carlow \\
\hline Ecosystem & Coniferous forest & Broadleaved forest & Grassland & Cropland \\
\hline & Pinus sylvestris & Fagus sylvatica & $\begin{array}{l}\text { Perennial ryegrass } \\
\text { and white clover }\end{array}$ & $\begin{array}{l}\text { Hordeum vulgare L. cv. } \\
\text { Tavern }\end{array}$ \\
\hline PFT & $\begin{array}{l}\text { 4: temperate } \\
\text { needleleaf } \\
\text { evergreen trees }\end{array}$ & $\begin{array}{l}\text { 6: temperate } \\
\text { broadleaf } \\
\text { summergreen trees }\end{array}$ & $\begin{array}{l}\text { 10: natural C3 } \\
\text { grass }\end{array}$ & $\begin{array}{l}\text { 12: agricultural C3 } \\
\text { grass }\end{array}$ \\
\hline \multicolumn{5}{|l|}{ Soil properties $^{\mathrm{a}}$} \\
\hline Soil classification & Arenosol & Cambisol & Luvisol & Cambisol \\
\hline $\mathrm{pH}$ & 4 & 6.7 & 7.3 & 7.6 \\
\hline Clay & 3.4 & 58.9 & 15 & 23 \\
\hline $\mathrm{BD}$ & 1.4 & 1.2 & 1.2 & 1.55 \\
\hline \multicolumn{5}{|l|}{ DOC measurements } \\
\hline Measurement depths $(\mathrm{cm})$ & $10,35,75$ & $5,10,20$ & $\begin{array}{l}\text { Topsoil }(10-30) \text {, } \\
\text { subsoil }(60-75)\end{array}$ & 40 \\
\hline Mean [DOC] per soil depth & $39.2,30.4,22.3$ & $16.7,9.2,6.6$ & $8.5,3.6$ & 4.2 \\
\hline No. of suction cups per horizon & $6,6,6$ & $4,4,4$ & 10,10 & 10 \\
\hline Measurement period & $2000-2008$ & $2001-2014$ & $2006-2009$ & 2006-2009 \\
\hline References & Gielen et al. (2011) & Kindler et al. (2011) & Kindler et al. (2011) & $\begin{array}{l}\text { Kindler et al. (2011); } \\
\text { Walmsley et al. (2011) }\end{array}$ \\
\hline \multicolumn{5}{|l|}{ Meteorological observations } \\
\hline Forcings & $\begin{array}{l}\text { FLUXNET } \\
(1997-2010)\end{array}$ & $\begin{array}{l}\text { FLUXNET } \\
(2000-2007)\end{array}$ & $\begin{array}{l}\text { FLUXNET } \\
(2004-2008)\end{array}$ & $\begin{array}{l}\text { FLUXNET } \\
(2004-2008)\end{array}$ \\
\hline
\end{tabular}

${ }^{a}$ Soil properties are averaged over the soil profile.

site by multiplying the SOC concentrations by the bulk density measured at each soil layer. Total stocks were obtained by summing up the stocks of each layer to the maximum depth of measurement.

\subsubsection{Model parameterization}

The soil carbon stocks in an LSM such as ORCHIDEE-SOM depend on primary production (Todd-Brown et al., 2013). Consequently, prior to the evaluation of the soil module in ORCHIDEE-SOM, we used gross primary production (GPP) measurements from the FLUXNET network to optimize the GPP-related parameters $\left(V_{\mathrm{cmax}}\right.$, surface leaf area, maximum leaf area index, minimum leaf area index to start photosynthesis, and minimum and maximum photosynthesis temperature sensitivity) in ORCHIDEE in order to ensure that model inputs coming from plant production are correct (Table S1 in the Supplement). The ORCHIDEE data assimilation system, based on a Bayesian optimization scheme, was used for the optimization (MacBean et al., 2016). The optimization approach relies on the iterative minimization of the mismatch between the set of experimental observations and corresponding model outputs by adjusting the model-driving parameters using the L-BFGS-B algorithm (Byrd et al., 1995).
The simulations were done by using the default parameter set of ORCHIDEE-SOM (Table 1), which are defined based on prior knowledge and values reported in the literature. Only the DOC turnover times and microbial CUE $\mathrm{DOC}_{\mathrm{C}}$ parameters were adjusted to site-specific conditions. For the Hainich forest and the Carlow grassland and cropland, where litter decomposes faster, the turnover time of the stable DOC was assumed to be equal to the turnover time of the labile DOC, which is 1.3 days (see Sect. 3.3). Microbial CUEDOC is a PFT-dependent parameter in the model that ranges from 0.3 to 0.55 (Table 1). While the mean measured CUE for soil microbial communities is 0.55 , the recommendation for broad spatial-scale models operating at long time steps is to use a CUE value of 0.3 (Manzoni et al., 2012; Sinsabaugh et al., 2013). Certainly, CUE shows a large variability and associated uncertainty, particularly in communities of terrestrial soils, as it is affected by multiple environmental factors and nutrient availability (Manzoni et al., 2012). Consequently, we selected the $\mathrm{CUE}_{\mathrm{DOC}}$ value within the reported range that performed best for each site simulation, namely 0.35 for Hainich and 0.5 for the other three sites. 

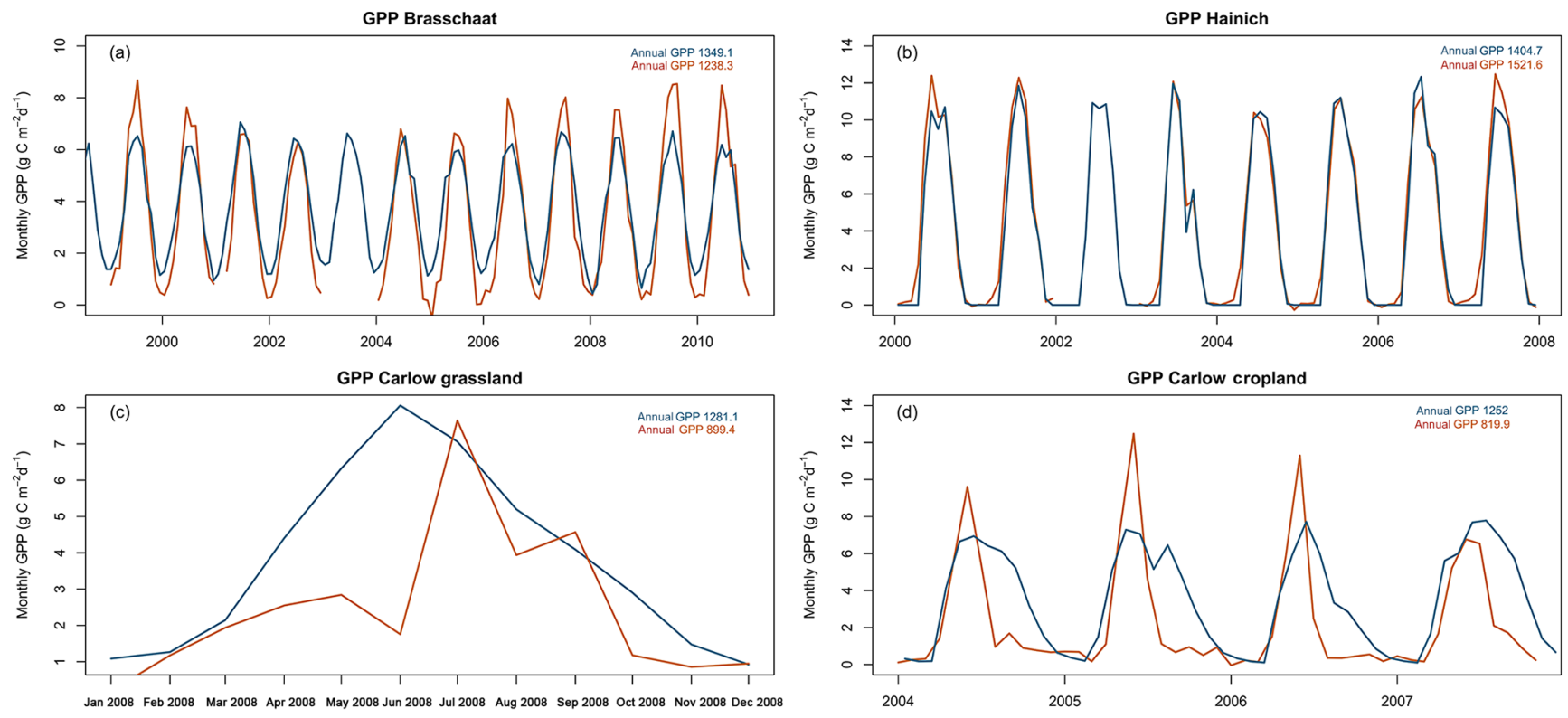

— Measured

- ORCHIDEE-SOM

Figure 2. Measured and modeled daily GPP (monthly means) at the four sites after GPP optimization: (a) Brasschaat forest, (b) Hainich forest, (c) Carlow grassland, and (d) Carlow cropland. Measured GPPs are acquired from each FLUXNET site and modeled GPP was acquired using ORCHIDEE-SOM.

\subsubsection{Model simulations on site}

The performance of the model was tested using data of DOC and SOC stocks at the four selected sites. Since these sites are all part of the FLUXNET network (Baldocchi et al., 2001), the in situ measured meteorological variables were available to be used as forcing for the simulations in ORCHIDEE. For Carlow grassland, only 1 year (2008) of flux measurements was available. However, Carlow grassland and cropland sites are located very close to each other and we therefore used the meteorological measurements of Carlow cropland as forcing for Carlow grassland. For all sites, the in situ meteorological data were gap-filled using the ERA-Interim 3-hourly product, following the methodology in Vuichard and Papale (2015).

Before the model application, we ran the model over approximately 14000 years repeatedly using the meteorological data for the available period for each site until all the soil variables reached a steady state (spin-up). The atmospheric $\mathrm{CO}_{2}$ concentration was held at $350 \mathrm{ppm}$ (Keeling and Whorf, 2006). For pH, clay content, and bulk density, site-specific observed values were used (Table 2). The state of the ecosystem at the last time step of the spin-up was then used as the initial state for the simulations over the four selected sites for the period with available flux measurements (Table 2). The site simulations were run at a daily time step to better explore the DOC temporal variations.

Goodness of fit for the monthly DOC measurements was assessed by calculating the coefficient of varia- tion of the NRMSE (\%), which is RMSE divided by the mean values of measurements, and then comparing the NRMSE values with the measurement uncertainty as standard deviation (SD) in percent. The goodness of fit of the model was defined as follows: "very good" for NRMSE $<\mathrm{SD}$, "good" for SD $<$ NRMSE $<\mathrm{SD}+30 \%$, "fair" for SD $+30 \%<\mathrm{NRMSE}<\mathrm{SD}+60 \%$, and "bad" for NRMSE $>$ SD $+60 \%$ (Table S2).

\section{Model results and discussion}

\subsection{GPP}

Accurate soil DOC simulations rely on the correct simulation of productivity, which in this study was approximated by optimizing the GPP modeled by ORCHIDEESOM at the study sites. After optimization of the GPPrelated parameters (Table S1), modeled and measured GPP were in good agreement for Brasschaat forest (modeled GPP of $1350 \pm 50 \mathrm{~g} \mathrm{Cm}^{-2} \mathrm{yr}^{-1}$ vs. measured GPP of $1240 \pm$ $\left.130 \mathrm{~g} \mathrm{C} \mathrm{m}^{-2} \mathrm{yr}^{-1}\right)$, Hainich forest $\left(1410 \pm 70 \mathrm{~g} \mathrm{Cm}^{-2} \mathrm{yr}^{-1}\right.$ vs. $\left.1520 \pm 110 \mathrm{~g} \mathrm{Cm}^{-2} \mathrm{yr}^{-1}\right)$, and Carlow cropland (1250 \pm $180 \mathrm{~g} \mathrm{C} \mathrm{m}^{-2} \mathrm{yr}^{-1}$ vs. $820 \pm 90 \mathrm{~g} \mathrm{Cm}^{-2} \mathrm{yr}^{-1}$; Fig. 2). The GPP of Carlow grassland simulations could not be optimized due to limited data availability since GPP measurements were available only for the year 2008. Consequently, modeled GPP in 2008 was $40 \%$ higher than measured GPP for the single year of measurement, mainly due to a longer growing season 

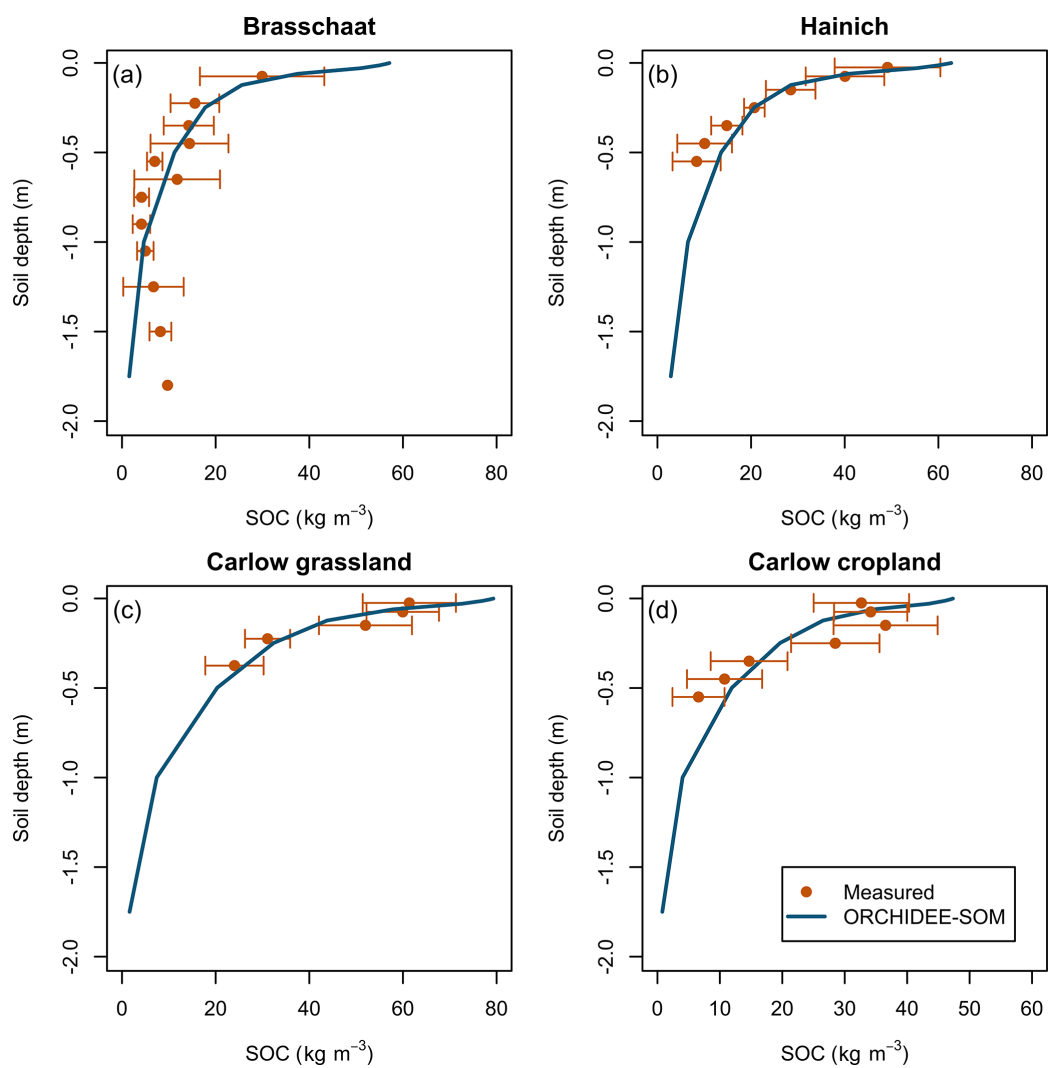

Figure 3. ORCHIDEE-SOM simulated (in blue) and measured (in brown) soil organic carbon profiles at the four sites, (a) Brasschaat forest, (b) Hainich forest, (c) Carlow grassland, and (d) Carlow cropland. Error bars represent the standard deviation of the measurements.

modeled by ORCHIDEE-SOM. Maximum GPP values were similar between the model and observations (Fig. 2c).

\subsection{SOC stocks and profiles}

Overall, the simulated total SOC stocks to $2 \mathrm{~m}$ of depth were in good agreement with the measured values (Table 3). ORCHIDEE-SOM was able to simulate total SOC stocks within the standard deviation of the measurements at the two forest sites (Fig. 3a and b), but overestimated SOC stocks by $6 \%$ in the grassland site and by $21 \%$ in the cropland site (Fig. 3c and d). Moreover, there was a good match between the measured and modeled SOC stocks at different soil depths at the four studied sites (Fig. 3), particularly at Brasschaat forest with measured depth to $>1.5 \mathrm{~m}$ (Fig. 3a). The SOC stock vertical profile was thus very well reproduced by the model, suggesting that the two processes defining the SOC pool distribution in the model, i.e., (1) the vertical distribution of litter $\mathrm{C}$ following the root $\mathrm{C}$ profiles and (2) the vertical transport of SOC through diffusion, were properly represented in ORCHIDEE-SOM.

We assumed that soil fauna is present everywhere along the soil profile, and thus the diffusion parameter was assumed to be constant along the soil profile in ORCHIDEE-SOM (Table 1). Because soil faunal activity may vary with depth, one could argue that the diffusion coefficient should be depth dependent. However, models with depth-dependent diffusion coefficients have been tested, but did not yield substantial improvements relative to models with a fixed diffusion coefficient (Boudreau, 1986). In fact, most of the models of diffusion at the ecosystem level assume a constant diffusion parameter with depth (Bruun et al., 2007; Guimberteau et al., 2018; O'Brien and Stout, 1978; Wynn et al., 2005). Our results confirm that this assumption is valid for four temperate sites with different vegetation inputs and soil properties.

\subsection{DOC dynamics at the site level}

The ORCHIDEE-SOM simulation of DOC concentration time series at the Brasschaat forest was in good agreement with the observed DOC concentrations in the intermediate soil layer $(35 \mathrm{~cm}, \mathrm{NRMSE}=35 \%$; Fig. $4 \mathrm{~b})$. However, it clearly overestimated the DOC concentrations in the upper soil layer $(10 \mathrm{~cm}, \mathrm{NRMSE}=228 \%$; Fig. $4 \mathrm{a})$ and underestimated DOC concentrations in the subsoil $(75 \mathrm{~cm}, \mathrm{NRMSE}=$ $58 \%$; Fig. 4c; Table S2). This coniferous forest showed the highest DOC concentrations ( $>20 \mathrm{mg} \mathrm{L}^{-1}$; Table 2), which partly originate from a "low-quality" litter, in this case needles, that decomposes more slowly and thus relatively more DOC remains in solution (Cotrufo et al., 2013; Zhang et al., 

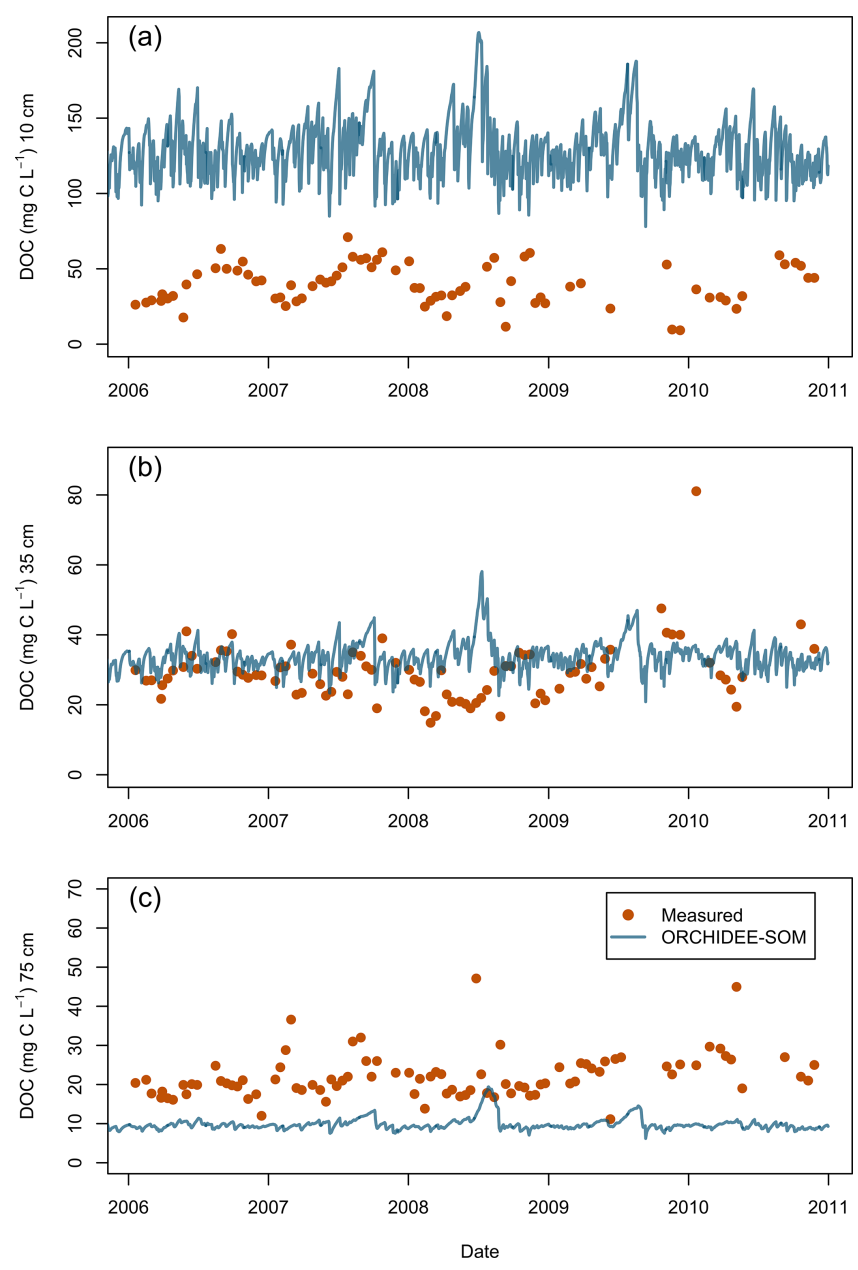

Figure 4. ORCHIDEE-SOM simulated (daily values) and measured DOC dynamics at Brasschaat forest at three soil depths: (a) $10 \mathrm{~cm}$, (b) $35 \mathrm{~cm}$, and (c) $75 \mathrm{~cm}$. Error bars are not displayed due to data unavailability.

2008). The higher turnover time for the stable DOC pool in the model accounts for the slower decomposition of DOC in the Brasschaat forest, producing a good fit to the observations in the intermediate $(35 \mathrm{~cm})$ and subsoil layers $(75 \mathrm{~cm})$, but overestimating DOC concentrations in the upper soil layer. For the rest of the sites (the deciduous forest, the grassland, and the cropland) where litter is more easily degradable, the turnover time of the stable DOC was assumed to be equal to the labile DOC pool, thus fitting the lower DOC concentrations at these sites.

In the case of Hainich forest, modeled DOC concentrations were in good agreement with the observed values, particularly in the upper soil layer $(5 \mathrm{~cm}, \mathrm{NRMSE}=30 \%$; Fig. 5a). The model tended to underestimate DOC concentrations in deeper soil layers $(10$ and $20 \mathrm{~cm}, \mathrm{NRMSE}=59$ and $83 \%$, respectively; Fig. $5 \mathrm{~b}$ and c), but the modeled DOC concentrations were mostly still inside the standard deviations of the observations for all depths (Fig. 5). In this case, the CUE $\mathrm{DOC}_{\mathrm{DOC}}$ parameter was decreased from 0.5 to 0.35 , a value that is in agreement with observed bacterial growth efficiency in the soil water matrix in a beech forest (Andreasson et al., 2009), to better capture the relatively low DOC concentrations observed in Hainich forest (median = $9.53 \mathrm{mg} \mathrm{L}^{-1}$, range $=1.5-50.7 \mathrm{mg} \mathrm{L}^{-1}$ ). The lower CUE in Hainich may be partly explained by the higher soil $\mathrm{pH}$ compared to Brasschaat coniferous forest (Table 2). Less acidic soils may contribute to lowering not only DOC concentrations in the soil solution of the Hainich forest (CaminoSerrano et al., 2014; Löfgren and Zetterberg, 2011), but also the microbial CUE that tends to decrease with increasing soil $\mathrm{pH}$, reaching a minimum at pH 7.0 (Sinsabaugh et al., 2016).

Finally, DOC concentrations simulated in Carlow grassland were mostly in good agreement with measurements (Fig. 6, Table S2; NRMSE $=33-66 \%$ ); only at the beginning of 2007 were the DOC concentrations in the topsoil slightly overestimated (Fig. 6a). The model better reproduced the topsoil DOC concentrations measured in Box 2, while the best fit in the subsoil was for the DOC concentrations measured in Box 1 (Table S2). Moreover, ORCHIDEE-SOM was able to reproduce the DOC magnitude time series in the cropland site well if we compare the simulated DOC at the 18$37 \mathrm{~cm}$ soil layer with the measurements from suction cups installed between 30 and $40 \mathrm{~cm}$ (Fig. 7; NRMSE $=29 \%$ ).

Even though the modeled DOC concentrations were overall within the range of variation of the measurements, ORCHIDEE-SOM was not able to fully capture the temporal dynamics of DOC concentrations at each site and soil layer (Figs. 4-7). This is not surprising taking into account that soil DOC is the result of multiple interconnected environmental, biological, and physicochemical factors, and as a consequence, DOC variability is very high in time and space (Clark et al., 2010). For instance, measured DOC in Carlow grassland was slightly higher in the sampling position Box 2 than in Box 1 (Fig. 6). Although these two sampling positions were only $150 \mathrm{~m}$ apart, the small-scale soil heterogeneity and the gentle slope leading from Box 1 to Box 2 caused the soil water contents to substantially differ between the two boxes (Fig. S4), leading to differences in DOC concentrations that cannot be captured in the model. Since a great proportion of DOC variability is explained by factors that are not accounted for in land surface models, such as metal complexion (Camino-Serrano et al., 2014), it is expected that daily DOC concentrations modeled by ORCHIDEE-SOM do not closely match spot measurements of DOC in soil solution. Nevertheless, at the four sites the magnitude of DOC concentrations was overall well captured by ORCHIDEE-SOM with the exception of the top layer in Brasschaat (Fig. 8), confirming the model applicability across a range of vegetation and soil types after parameter adjustment for $\mathrm{CUE}_{\mathrm{DOC}}$ at Hainich and turnover times of stable DOC in Hainich forest and Carlow grassland and cropland.

While the SOC profiles were well captured by ORCHIDEE-SOM, it was difficult to accurately simu- 
Table 3. Simulated and observed mean soil organic carbon (SOC) stocks in the selected sites. Simulated SOC stocks were calculated down to the sampling depth at each site. Values are means $\pm \mathrm{SD}$.

\begin{tabular}{lrrr}
\hline & & \multicolumn{2}{c}{ Soil carbon stocks $\left(\mathrm{kg} \mathrm{C} \mathrm{m}^{-2}\right)$} \\
\cline { 3 - 4 } Site & Sampling depth $(\mathrm{cm})$ & Measured & Modeled \\
\hline Brasschaat & 100 & $12.1 \pm 3.1$ & 14.15 \\
Hainich & 60 & $12.4 \pm 1.54$ & 12.95 \\
Carlow grassland & 40 & 16.6 & 17.6 \\
Carlow cropland & 60 & $9.41 \pm 1.5$ & 11.4 \\
\hline
\end{tabular}
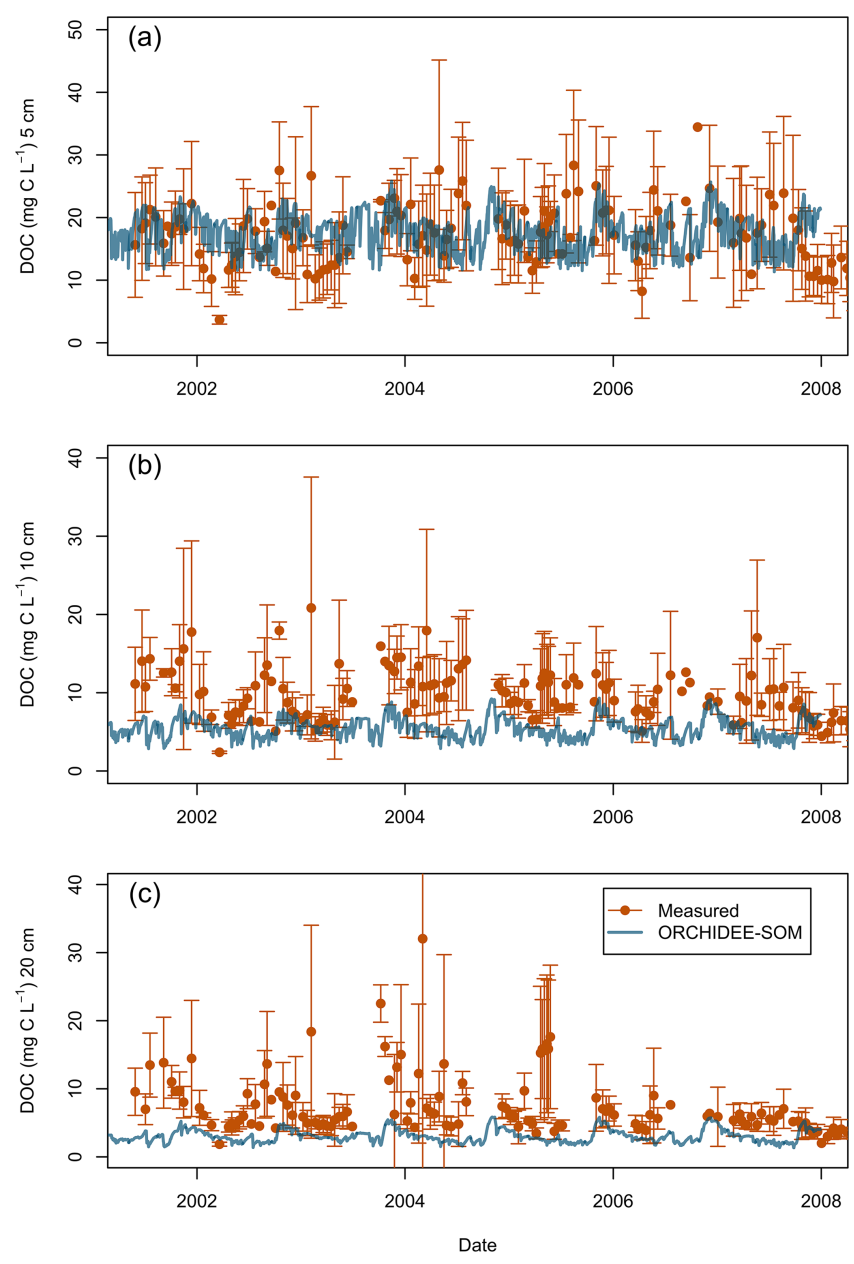

Figure 5. ORCHIDEE-SOM simulated (daily values) and measured DOC dynamics at Hainich forest at three soil depths: (a) $5 \mathrm{~cm}$, (b) $10 \mathrm{~cm}$, and (c) $20 \mathrm{~cm}$. Error bars represent the standard deviation of site measurements $(n=4)$.

late DOC concentrations along the different soil depths at the site level using the default parameters. Interestingly, the model was not very sensitive to parameters that directly affect the vertical distribution of carbon, such as the SOC and DOC diffusion coefficient. On the contrary, it showed the greatest sensitivity to the biological parameters: the
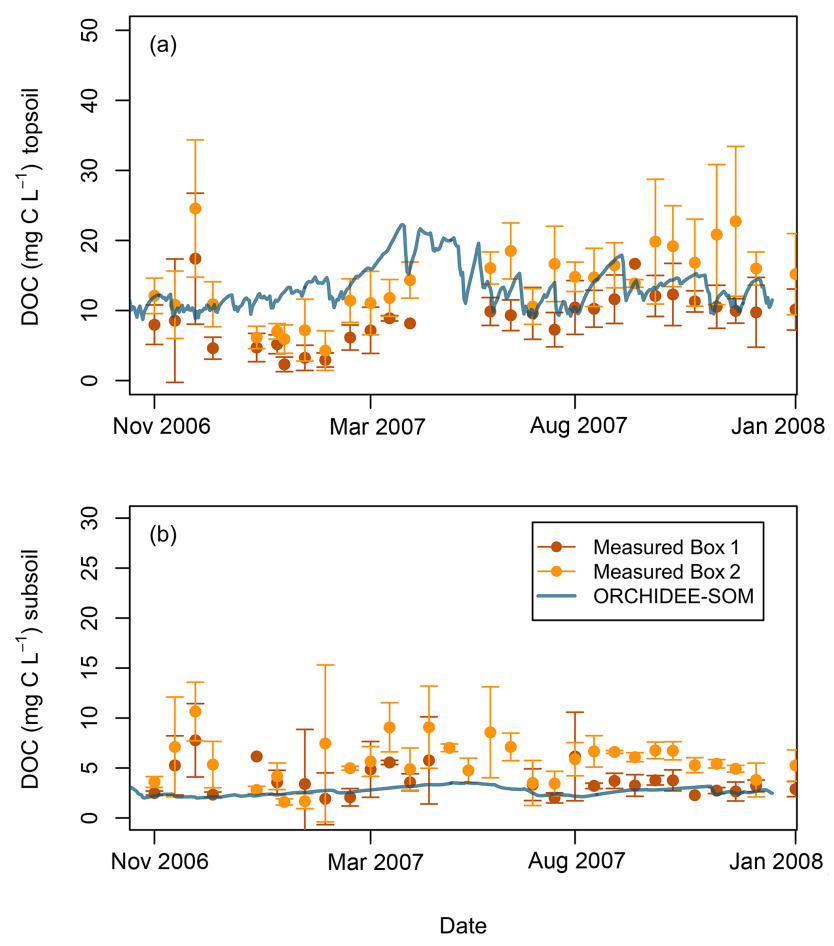

Figure 6. ORCHIDEE-SOM simulated (daily values) and measured DOC dynamics at Carlow grassland at two soil layers: (a) topsoil $10-30 \mathrm{~cm}$ and (b) subsoil $60-75 \mathrm{~cm}$. Site measurements are in brown for Box 1 and in orange for Box 2, and simulation results using ORCHIDEE-SOM (daily values) are in blue. Error bars represent the standard deviation of site measurements $(n=5)$.

turnover time of DOC and the CUE ${ }_{\text {DOC }}$ (Table S3, Figs. S6 and S7). DOC in soils is primarily the result of the enzymatic decomposition of litter and SOC, and it also originates from root exudates and from microbial residues that are not explicitly modeled. Simultaneously, microbial consumption of DOC is the main process of DOC removal from soil (Bolan et al., 2011). Since both are biological processes, it explains the high model sensitivity to these biological parameters. DOC production and consumption are both controlled by the same factors that control biological activity, particularly temperature and moisture, and these processes will therefore vary with soil depth, land use type, and soil fertility (Bolan 


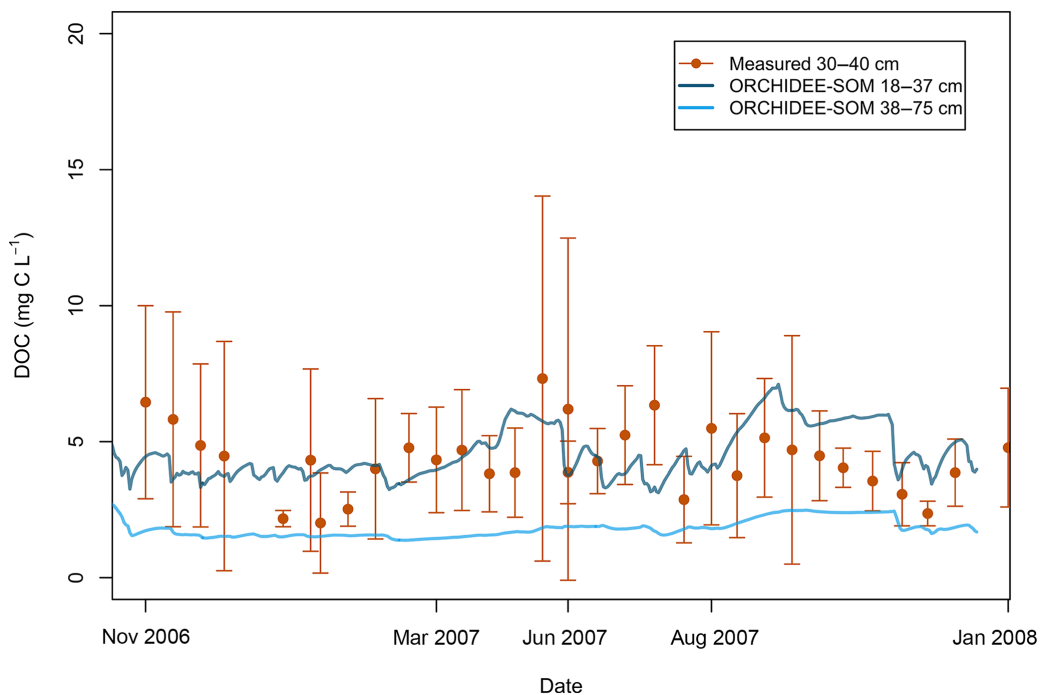

Figure 7. ORCHIDEE-SOM simulated (daily values) and measured DOC dynamics at Carlow cropland measured between 30 and $40 \mathrm{~cm}$. Error bars represent the standard deviation of site measurements $(n=10)$.

et al., 2011). However, these interactions are not represented in the model.

\subsection{Model limitations and further work}

In this study, ORCHIDEE-SOM was tested at four temperate ecosystems in Europe, but additional considerations need to be taken into account when applying the model to other ecosystems. For instance, the DOC coming from throughfall is not represented in ORCHIDEE-SOM, although it is a substantial source of soil DOC in tropical ecosystems (Lauerwald et al., 2017). Furthermore, the use of the hydrological module ORC11, which implies free drainage in the bottom layer, currently limits the representation of more humid ecosystems, such as wetlands or peatlands where shallow water tables are present, and needs to be addressed in the near future.

Moreover, it is important to note that the modeled DOC along the soil profile strongly depends on the downward water flux simulated by the hydrological module ORC11. Therefore, the accuracy of the simulated DOC fluxes relies on the accuracy of the simulated soil water flux. However, while soil water content (SWC) is frequently measured in the field (Figs. S2-S5), there are no site-level measurements of internal soil water fluxes, and therefore soil water fluxes between layers cannot be validated against observations, thereby introducing a source of uncertainty in ORCHIDEE-SOM.

A general simplification of the model is that only the mineral soil is explicitly represented. The aboveground litter is dimensionless and the products of its decomposition are redistributed among the first five soil layers. As a consequence, these layers contain the organic material, but do not explicitly account for the substantially different hydrological, chemi- cal, and physical processes that occur between organic materials and mineral soil layers. Although the current version of ORCHIDEE-SOM performed well at the Hainich forest (Fig. 5), the misrepresentation of the organic horizons (e.g., differentiation of humus types) may partly explain the deviance in DOC predictions in the upper soil layer of the Brasschaat forest (Fig. 4a). Overall, representing only the mineral soil layers may limit the model application in forest soil with potentially large organic horizons, such as Podzols and Gleysols, or more importantly in organic soils such as peatlands. Moreover, for technical reasons, the mineral soil in our model is divided into synthetic soil layers following the ORC11 vertical discretization; i.e., we do not differentiate between different physical layers by defining horizon types with distinctive transport properties or parameters. Therefore, further work should consider explicitly modeling organic and mineral horizons defined by their biogeochemical and physical differences. Besides improving soil representation in ORCHIDEE-SOM, it will facilitate modelmeasurement comparisons.

Along these lines, ORCHIDEE-SOM does not represent important pedogenic processes, such as organo-mineral complexation, podsolization, clay migration, or soil aggregation. Several studies have recognized these processes as key emergent properties for understanding soil $\mathrm{C}$ dynamics; however, they have not yet been explicitly integrated into land surface models (Davidson et al., 2014; Finke and Hutson, 2008; Schmidt et al., 2011). Since it is not feasible to incorporate all the involved factors and processes into a global soil model, further research is still needed to elucidate which processes should be explicitly represented and which can be neglected in order to achieve the best simulations and predictions of SOC dynamics (Luo et al., 2016). 


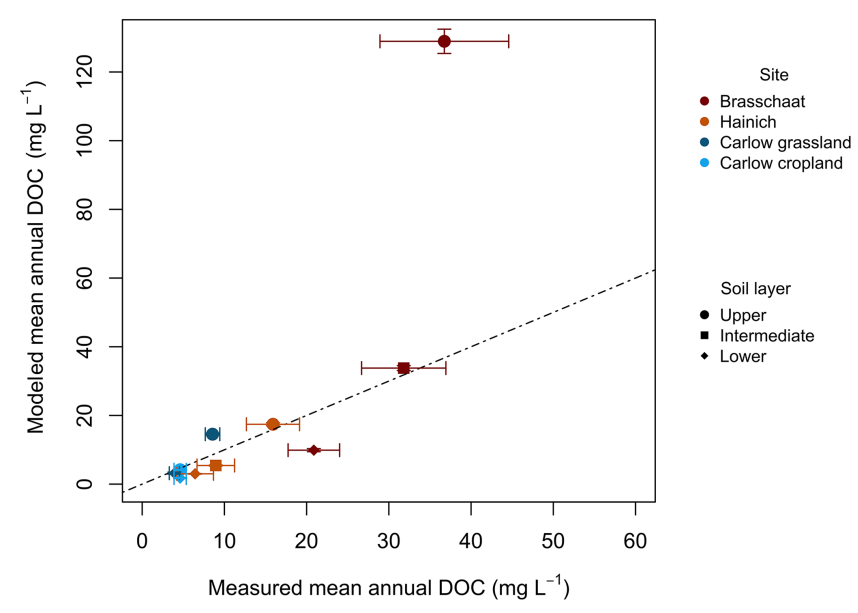

Figure 8. Measured vs. modeled mean annual DOC concentrations $\left(\mathrm{mgCL}^{-1}\right)$. Error bars represent the standard deviations for the mean annual DOC concentrations. The dashed line represents the $1: 1$ line.

Future model applications will require further empirical parameterization. Several studies highlight the importance of soil properties and vegetation characteristics in SOC-related parameters, such as the effect of soil type and litter decomposability (humus type) on microbes (Sulman et al., 2014) or the effect of soil texture, SOC content, and bulk density on the moisture-soil respiration relationship (Moyano et al., 2012). We applied an empirical relationship that links the adsorption coefficient $\left(K_{\mathrm{D}}\right)$ with soil properties (clay and $\mathrm{pH}$; Eq. 15) as a first step towards linking the physicochemical soil properties to our model parameters, although the correlation was weak and some important parameters (Al or Fe in soils) are still missing. A similar exercise should be done for biological model parameters like $\mathrm{CUE}_{\mathrm{DOC}}$, which for the moment do not reflect their known changes with vegetation or soil properties (Manzoni et al., 2017; Sinsabaugh et al., 2016). Also, the SOC diffusion coefficient was kept constant along the soil profile, although it is known that diffusion is higher in the upper soil layers and that biotic activity is controlled by the pH, among other factors (Jagercikova et al., 2014). Our findings thus point to the necessity of a depthand vegetation-dependent parameterization of the new model parameters in the future.

Finally, our results showed that the model performed worst at Brasschaat, which is the site with the most extreme soil conditions (very acidic and sandy soil). It is not surprising that ORCHIDEE-SOM, which is designed for regional or global simulations, is unable to reproduce SOC and DOC dynamics well at sites with particular characteristics because it uses many default parameters based on prior knowledge (Table 1).

Additional parameter optimization through data assimilation at the multisite level is thus needed before applying ORCHIDEE-SOM to large-scale simulations. Calibration of the new parameters of ORCHIDEE-SOM by assimilation of DOC concentration and SOC stock data from several sites across different biomes will not only make the model applicable to large-scale simulations, but will also give insight into the relative importance of processes affecting SOC and DOC in different ecosystem types (Braakhekke et al., 2013); it will also reduce the uncertainty range of the new parameters, which is an essential part of any process-based largescale model (Zaehle et al., 2005).

We present here a new soil module within the land surface model ORCHIDEE. This module keeps the pool-based structure of the CENTURY model, but is upgraded to represent the biological production and consumption, mineral sorption, and transport of vertically discretized SOC and DOC. None of the existing soil models that represent all these DOCrelated processes and that vertically discretized SOC are embedded within a land surface model. ORCHIDEE-SOM is an intermediate complexity model that despite its simplicity and generalization has proven successful in simulating soil solution DOC concentrations at four different ecosystem types (Fig. 8). Once the soil module in ORCHIDEE-SOM is optimized for large-scale simulations and linked to the existing DOC river scheme (Lauerwald et al., 2017), it will improve the predictions of SOC vulnerability to climate change and the predictions of the present and future contribution of aquatic continuum fluxes to the global $\mathrm{C}$ cycle, thus improving the allocation of terrestrial and ocean $\mathrm{C}$ sinks.

\section{Conclusions}

ORCHIDEE-SOM is a new vertically resolved soil module embedded in the land surface model ORCHIDEE that represents litter, SOC and DOC dynamics, and transport in and out of the soil. Key model improvements compared to the trunk version of ORCHIDEE are that ORCHIDEE-SOM can simulate deep SOC dynamics (vertical profiles of SOC) and loss of organic carbon through leaching. We evaluated the model for four European sites with different vegetation covers using input parameters that are realistic compared to prior knowledge. The modeled SOC stock profiles agree very well with the observations. Overall, the model was able to reproduce DOC concentrations at different soil depths, although DOC concentrations were overestimated in the upper horizon at the coniferous forest.

Moving forward requires an exhaustive model parameterization. Our results suggest that empirical data should be integrated into the SOC and DOC turnover times and CUE ${ }_{D O C}$ parameters in order to make them soil and vegetation dependent. Moreover, to be able to run ORCHIDEE-SOM on regional or global scales, the new parameters should be optimized by data assimilation and the optimized model needs testing against observations of SOC and DOC on larger scales (continental or global). 
With our work on ORCHIDEE-SOM, we prepared the necessary model structure to simulate deep SOC and DOC dynamics by implementing the processes of DOC production and decomposition, DOC adsorption and desorption in mineral soils, SOC bioturbation, and DOC transport with water flux. Although the current model still requires exhaustive parameterization, we conclude that by improving each of these new model elements we have the opportunity to end up with a robust, albeit simple and general, global tool for the prediction of soil carbon fluxes and leaching to rivers and lakes.

Code availability. The SVN version of the code branch is https:// forge.ipsl.jussieu.fr/orchidee/browser/branches/ORCHIDEE-SOM (last access: 8 March 2018) revision 4407 and is available upon request. The ORCHIDEE data assimilation tool is available through a dedicated website: https://orchidas.lsce.ipsl.fr (last access: 8 March 2018).

\section{The Supplement related to this article is available online at https://doi.org/10.5194/gmd-11-937-2018-supplement.}

Author contributions. MC, BGu, IJ, SL, PC, and JP conceived the study. MCS and BGu performed all the simulations. RL and AJP optimized the code and assisted with technical aspects of the model. VB provided and assisted with the optimization tool (ORCHIDAS) and NV provided and assisted with the preparation of the forcing files using FLUXNET data. BdV, BGi, GG, MS, and DW provided the site measurements and other site information needed for the model evaluation. KK and DK provided the adsorption isotherm datasets, and SV assisted with the statistics for the adsorption function. All the authors wrote the paper.

Competing interests. The authors declare that they have no conflict of interest.

Acknowledgements. This work used eddy covariance data acquired and shared by the FLUXNET community, including these networks: AmeriFlux, AfriFlux, AsiaFlux, CarboAfrica, CarboEuropeIP, CarboItaly, CarboMont, ChinaFlux, FluxnetCanada, GreenGrass, ICOS, KoFlux, LBA, NECC, OzFlux-TERN, TCOS-Siberia, and USCCC. The ERA-Interim reanalysis data are provided by ECMWF and processed by LSCE. The FLUXNET eddy covariance data processing and harmonization was carried out by the European Fluxes Database Cluster, AmeriFlux Management Project, and Fluxdata project of FLUXNET, with the support of CDIAC, ICOS Ecosystem Thematic Center, and the OzFlux, ChinaFlux, and AsiaFlux offices. Marta Camino-Serrano, Philippe Ciais, Jopes Peñuelas, and Ivan A. Janssens acknowledge funding from the European Research Council Synergy grant ERC-2013-SyG-610028 IMBALANCE-P. Ronny Lauerwald acknowledges funding from the European Union Horizon 2020 research and innovation program under grant agreement no. 703813 for the Marie Sklodowska-Curie European Individual Fellowship "C-Leak". Bertrand Guenet acknowledges funding from the ANR14-CE01-0004 DeDyCAS project. Sara Vicca is a postdoctoral research associate of the Fund for Scientific Research, Flanders.

Edited by: David Lawrence

Reviewed by: two anonymous referees

\section{References}

Ahrens, B., Braakhekke, M. C., Guggenberger, G., Schrumpf, M., and Reichstein, M.: Contribution of sorption, DOC transport and microbial interactions to the ${ }^{14} \mathrm{C}$ age of a soil organic carbon profile: Insights from a calibrated process model, Soil Biol. Biochem., 88, 390-402, https://doi.org/10.1016/J.SOILBIO.2015.06.008, 2015.

Andreasson, F., Bergkvist, B., and Bååth, E.: Bioavailability of DOC in leachates, soil matrix solutions and soil water extracts from beech forest floors, Soil Biol. Biochem., 41, 1652-1658, https://doi.org/10.1016/j.soilbio.2009.05.005, 2009.

Baldocchi, D., Falge, E., Gu, L., Olson, R., Hollinger, D., Running, S., Anthoni, P., Bernhofer, C., Davis, K., Evans, R., Fuentes, J., Goldstein, A., Katul, G., Law, B., Lee, X., Malhi, Y., Meyers, T., Munger, W., Oechel, W., Paw, K. T., Pilegaard, K., Schmid, H. P., Valentini, R., Verma, S., Vesala, T., Wilson, K., and Wofsy, S.: FLUXNET: A New Tool to Study the Temporal and Spatial Variability of Ecosystem-Scale Carbon Dioxide, Water Vapor, and Energy Flux Densities, B. Am. Meteorol. Soc., 82, 2415-2434, https://doi.org/10.1175/15200477(2001)082<2415:FANTTS>2.3.CO;2, 2001.

Battin, T. J., Luyssaert, S., Kaplan, L. A., Aufdenkampe, A. K., Richter, A., and Tranvik, L. J.: The boundless carbon cycle, Nat. Geosci., 2, 598-600, https://doi.org/10.1038/Ngeo618, 2009.

Boddy, E., Hill, P. W., Farrar, J., and Jones, D. L.: Fast turnover of low molecular weight components of the dissolved organic carbon pool of temperate grassland field soils, Soil Biol. Biochem., 39, 827-835, https://doi.org/10.1016/j.soilbio.2006.09.030, 2007.

Boddy, E., Roberts, P., Hill, P. W., Farrar, J., and Jones, D. L.: Turnover of low molecular weight dissolved organic C (DOC) and microbial $\mathrm{C}$ exhibit different temperature sensitivities in Arctic tundra soils, Soil Biol. Biochem., 40, 1557-1566, https://doi.org/10.1016/j.soilbio.2008.01.030, 2008.

Bolan, N. S., Adriano, D. C., Kunhikrishnan, A., James, T., McDowell, R., and Senesi, N.: Dissolved Organic Matter: Biogeochemistry, Dynamics, and Environmental Significance in Soils, Adv. Agron., 110, 1-75, https://doi.org/10.1016/B978-012-385531-2.00001-3, 2011.

Boudreau, B. P.: Mathematics of Tracer Mixing in Sediments. 1. Spatially-Dependent, Diffusive Mixing, Am. J. Sci., 286, 161198, 1986.

Braakhekke, M. C., Beer, C., Hoosbeek, M. R., Reichstein, M., Kruijt, B., Schrumpf, M., and Kabat, P.: SOMPROF: A vertically explicit soil organic matter model, Ecol. Model., 222, 17121730, https://doi.org/10.1016/j.ecolmodel.2011.02.015, 2011.

Braakhekke, M. C., Wutzler, T., Beer, C., Kattge, J., Schrumpf, M., Ahrens, B., Schöning, I., Hoosbeek, M. R., Kruijt, B., Kabat, 
P., and Reichstein, M.: Modeling the vertical soil organic matter profile using Bayesian parameter estimation, Biogeosciences, 10, 399-420, https://doi.org/10.5194/bg-10-399-2013, 2013.

Bradford, M. A., Wieder, W. R., Bonan, G. B., Fierer, N., Raymond, P. A., and Crowther, T. W.: Managing uncertainty in soil carbon feedbacks to climate change, Nat. Clim. Change, 6, 751758, https://doi.org/10.1038/nclimate3071, 2016.

Bruun, S., Christensen, B. T., Thomsen, I. K., Jensen, E. S., and Jensen, L. S.: Modeling vertical movement of organic matter in a soil incubated for 41 years with C14 labeled straw, Soil Biol. Biochem., 39, 368-371, https://doi.org/10.1016/j.soilbio.2006.07.003, 2007.

Buckingham, E.: Studies on the Movement of Soil Moisture, US Government Printing Office, Washington, 1907.

Burdige, D. J., Berelson, W. M., Coale, K. H., McManus, J., and Johnson, K. S.: Fluxes of dissolved organic carbon from California continental margin sediments, Geochim. Cosmochim. Ac., 63, 1507-1515, https://doi.org/10.1016/S0016-7037(99)000666, 1999.

Byrd, R. H., Lu, P., Nocedal, J., and Zhu, C.: A Limited Memory Algorithm for Bound Constrained Optimization, SIAM J. Sci. Comput., 16, 1190-1208, https://doi.org/10.1137/0916069, 1995.

Camino-Serrano, M., Gielen, B., Luyssaert, S., Ciais, P., Vicca, S., Guenet, B., Vos, B. De, Cools, N., Ahrens, B., Altaf Arain, M., Borken, W., Clarke, N., Clarkson, B., Cummins, T., Don, A., Pannatier, E. G., Laudon, H., Moore, T., Nieminen, T. M., Nilsson, M. B., Peichl, M., Schwendenmann, L., Siemens, J., and Janssens, I.: Linking variability in soil solution dissolved organic carbon to climate, soil type, and vegetation type, Global Biogeochem. Cy., 28, GB004726, https://doi.org/10.1002/2013gb004726, 2014.

Campoy, A., Ducharne, A., Cheruy, F., Hourdin, F., Polcher, J., and Dupont, J. C.: Response of land surface fluxes and precipitation to different soil bottom hydrological conditions in a general circulation model, J. Geophys. Res.-Atmos., 118, 10725-10739, https://doi.org/10.1002/Jgrd.50627, 2013.

Clark, J. M., Bottrell, S. H., Evans, C. D., Monteith, D. T., Bartlett, R., Rose, R., Newton, R. J., and Chapman, P. J.: The importance of the relationship between scale and process in understanding long-term DOC dynamics, Sci. Total Environ., 408, 2768-2775, https://doi.org/10.1016/j.scitotenv.2010.02.046, 2010.

Cotrufo, M. F., Wallenstein, M. D., Boot, C. M., Denef, K., and Paul, E.: The Microbial Efficiency-Matrix Stabilization (MEMS) framework integrates plant litter decomposition with soil organic matter stabilization: do labile plant inputs form stable soil organic matter?, Glob. Change Biol., 19, 988-995, https://doi.org/10.1111/Gcb.12113, 2013.

Darcy, H.: Les fontaines de la ville de Dijon, Victor Dalmont, Paris, 1856.

Davidson, E. A., Savage, K. E., and Finzi, A. C.: A big-microsite framework for soil carbon modeling, Glob. Change Biol., 20, 3610-3620, https://doi.org/10.1111/gcb.12718, 2014.

de Rosnay, P., Polcher, J., Bruen, M., and Laval, K.: Impact of a physically based soil water flow and soil-plant interaction representation for modeling large-scale land surface processes, J. Geophys. Res.-Atmos., 107, ACL 3-1-ACL 3-19, https://doi.org/10.1029/2001jd000634, 2002.
d'Orgeval, T., Polcher, J., and de Rosnay, P.: Sensitivity of the West African hydrological cycle in ORCHIDEE to infiltration processes, Hydrol. Earth Syst. Sci., 12, 1387-1401, https://doi.org/10.5194/hess-12-1387-2008, 2008.

Dwivedi, D., Riley, W. J., Torn, M. S., Spycher, N., Maggi, F., and Tang, J. Y.: Mineral properties, microbes, transport, and plant-input profiles control vertical distribution and age of soil carbon stocks, Soil Biol. Biochem., 107, 244-259, https://doi.org/10.1016/j.soilbio.2016.12.019, 2017.

Elzein, A. and Balesdent, J.: Mechanistic Simulation of Vertical Distribution of Carbon Concentrations and Residence Times in Soils, Soil Sci. Soc. Am. J., 59, 1328-1335, https://doi.org/10.2136/sssaj1995.03615995005900050019x, 1995.

Finke, P. A. and Hutson, J. L.: Modelling soil genesis in calcareous loess, Geoderma, 145, 462-479, https://doi.org/10.1016/j.geoderma.2008.01.017, 2008.

Fontaine, S., Barot, S., Barre, P., Bdioui, N., Mary, B., and Rumpel, C.: Stability of organic carbon in deep soil layers controlled by fresh carbon supply, Nature, 450, 277-280, https://doi.org/10.1038/Nature06275, 2007.

Futter, M. N., Butterfield, D., Cosby, B. J., Dillon, P. J., Wade, A. J., and Whitehead, P. G.: Modeling the mechanisms that control in-stream dissolved organic carbon dynamics in upland and forested catchments, Water Resour. Res., 43, W02424, https://doi.org/10.1029/2006wr004960, 2007.

Gervois, S., Ciais, P., de Noblet-Ducoudre, N., Brisson, N., Vuichard, N., and Viovy, N.: Carbon and water balance of European croplands throughout the 20th century, Global Biogeochem. Cy., 22, Gb2022, https://doi.org/10.1029/2007gb003018, 2008.

Gielen, B., Neirynck, J., Luyssaert, S., and Janssens, I. A.: The importance of dissolved organic carbon fluxes for the carbon balance of a temperate Scots pine forest, Agr. Forest Meteorol., 151, 270-278, https://doi.org/10.1016/j.agrformet.2010.10.012, 2011.

Gjettermann, B., Styczen, M., Hansen, H. C. B., Vinther, F. P., and Hansen, S.: Challenges in modelling dissolved organic matter dynamics in agricultural soil using DAISY, Soil Biol. Biochem., 40, 1506-1518, https://doi.org/10.1016/j.soilbio.2008.01.005, 2008.

Gleixner, G.: Soil organic matter dynamics: a biological perspective derived from the use of compound-specific isotopes studies, Ecol. Res., 28, 683-695, https://doi.org/10.1007/s11284012-1022-9, 2013.

Gouttevin, I., Krinner, G., Ciais, P., Polcher, J., and Legout, C.: Multi-scale validation of a new soil freezing scheme for a landsurface model with physically-based hydrology, The Cryosphere, 6, 407-430, https://doi.org/10.5194/tc-6-407-2012, 2012.

Guenet, B., Eglin, T., Vasilyeva, N., Peylin, P., Ciais, P., and Chenu, C.: The relative importance of decomposition and transport mechanisms in accounting for soil organic carbon profiles, Biogeosciences, 10, 2379-2392, https://doi.org/10.5194/bg-102379-2013, 2013.

Guenet, B., Moyano, F. E., Peylin, P., Ciais, P., and Janssens, I. A.: Towards a representation of priming on soil carbon decomposition in the global land biosphere model ORCHIDEE (version 1.9.5.2), Geosci. Model Dev., 9, 841-855, https://doi.org/10.5194/gmd-9-841-2016, 2016.

Guenet, B., Camino-Serrano, M., Ciais, P., Tifafi, M., Maignan, F., Soong, J. L., and Janssens, I. A.: Impact of 
priming on global soil carbon stocks, Glob. Change Biol., https://doi.org/10.1111/gcb.14069, 2018.

Guimberteau, M., Ducharne, A., Ciais, P., Boisier, J. P., Peng, S., De Weirdt, M., and Verbeeck, H.: Testing conceptual and physically based soil hydrology schemes against observations for the Amazon Basin, Geosci. Model Dev., 7, 1115-1136, https://doi.org/10.5194/gmd-7-1115-2014, 2014.

Guimberteau, M., Zhu, D., Maignan, F., Huang, Y., Yue, C., DantecNédélec, S., Ottlé, C., Jornet-Puig, A., Bastos, A., Laurent, P., Goll, D., Bowring, S., Chang, J., Guenet, B., Tifafi, M., Peng, S., Krinner, G., Ducharne, A., Wang, F., Wang, T., Wang, X., Wang, Y., Yin, Z., Lauerwald, R., Joetzjer, E., Qiu, C., Kim, H., and Ciais, P.: ORCHIDEE-MICT (v8.4.1), a land surface model for the high latitudes: model description and validation, Geosci. Model Dev., 11, 121-163, https://doi.org/10.5194/gmd-11-1212018, 2018.

Hoogsteen, M. J. J., Lantinga, E. A., Bakker, E. J., Groot, J. C. J., and Tittonell, P. A.: Estimating soil organic carbon through loss on ignition: effects of ignition conditions and structural water loss, Eur. J. Soil Sci., 66, 320-328, https://doi.org/10.1111/ejss.12224, 2015.

Hurtt, G. C., Chini, L. P., Frolking, S., Betts, R. A., Feddema, J., Fischer, G., Fisk, J. P., Hibbard, K., Houghton, R. A., Janetos, A., Jones, C. D., Kindermann, G., Kinoshita, T., Klein Goldewijk, K., Riahi, K., Shevliakova, E., Smith, S., Stehfest, E., Thomson, A., Thornton, P., van Vuuren, D. P., and Wang, Y. P.: Harmonization of land-use scenarios for the period 1500-2100: 600 years of global gridded annual land-use transitions, wood harvest, and resulting secondary lands, Clim. Change, 109, 117161, https://doi.org/10.1007/s10584-011-0153-2, 2011.

Jackson, R. B., Banner, J. L., Jobbagy, E. G., Pockman, W. T., and Wall, D. H.: Ecosystem carbon loss with woody plant invasion of grasslands, Nature, 418, 623-626, https://doi.org/10.1038/Nature00910, 2002.

Jagercikova, M., Evrard, O., Balesdent, J., Lefèvre, I., and Cornu, S.: Modeling the migration of fallout radionuclides to quantify the contemporary transfer of fine particles in Luvisol profiles under different land uses and farming practices, Soil Till. Res., 140, 82-97, https://doi.org/10.1016/J.STILL.2014.02.013, 2014.

Janssens, I. A., Sampson, D. A., Cermak, J., Meiresonne, L., Riguzzi, F., Overloop, S., and Ceulemans, R.: Aboveand belowground phytomass and carbon storage in a Belgian Scots pine stand, Ann. For. Sci., 56, 81-90, https://doi.org/10.1051/forest:19990201, 1999.

Janssens, I. A., Freibauer, A., Ciais, P., Smith, P., Nabuurs, G. J., Folberth, G., Schlamadinger, B., Hutjes, R. W. A., Ceulemans, R., Schulze, E. D., Valentini, R., and Dolman, A. J.: Europe's terrestrial biosphere absorbs 7 to $12 \%$ of European anthropogenic $\mathrm{CO}_{2}$ emissions, Science, 300, 1538-1542, https://doi.org/10.1126/science.1083592, 2003.

Jardine, P. M., Weber, N. L., and Mccarthy, J. F.: Mechanisms of Dissolved Organic-Carbon Adsorption on Soil, Soil Sci. Soc. Am. J., 53, 1378-1385, 1989.

Jobbagy, E. G. and Jackson, R. B.: The vertical distribution of soil organic carbon and its relation to climate and vegetation, Ecol. Appl., 10, 423-436, https://doi.org/10.2307/2641104, 2000.

Jutras, M. F., Nasr, M., Castonguay, M., Pit, C., Pomeroy, J. H., Smith, T. P., Zhang, C. F., Ritchie, C. D., Meng, F. R.,
Clair, T. A., and Arp, P. A.: Dissolved organic carbon concentrations and fluxes in forest catchments and streams: DOC-3 model, Ecol. Model., 222, 2291-2313, https://doi.org/10.1016/j.ecolmodel.2011.03.035, 2011.

Kaiser, K. and Kalbitz, K.: Cycling downwards - dissolved organic matter in soils, Soil Biol. Biochem., 52, 29-32, https://doi.org/10.1016/j.soilbio.2012.04.002, 2012.

Kaiser, K., Guggenberger, G., and Zech, W.: Sorption of DOM and DOM fractions to forest soils, Geoderma, 74, 281-303, https://doi.org/10.1016/S0016-7061(96)00071-7, 1996.

Kalbitz, K., Schmerwitz, J., Schwesig, D., and Matzner, E.: Biodegradation of soil-derived dissolved organic matter as related to its properties, Geoderma, 113, 273-291, https://doi.org/10.1016/S0016-7061(02)00365-8, 2003.

Keeling, C. D. and Whorf, T. P.: Atmospheric $\mathrm{CO}_{2}$ records from sites in the SIO air sampling network, Oak Ridge Natl. Lab. US Dept. or Energy, Oak Ridge, TN, 2006.

Kindler, R., Siemens, J., Kaiser, K., Walmsley, D. C., Bernhofer, C., Buchmann, N., Cellier, P., Eugster, W., Gleixner, G., Grunwald, T., Heim, A., Ibrom, A., Jones, S. K., Jones, M., Klumpp, K., Kutsch, W., Larsen, K. S., Lehuger, S., Loubet, B., McKenzie, R., Moors, E., Osborne, B., Pilegaard, K., Rebmann, C., Saunders, M., Schmidt, M. W. I., Schrumpf, M., Seyfferth, J., Skiba, U., Soussana, J. F., Sutton, M. A., Tefs, C., Vowinckel, B., Zeeman, M. J., and Kaupenjohann, M.: Dissolved carbon leaching from soil is a crucial component of the net ecosystem carbon balance, Glob. Change Biol., 17, 1167-1185, https://doi.org/10.1111/j.1365-2486.2010.02282.x, 2011.

Koarashi, J., Hockaday, W. C., Masiello, C. A., and Trumbore, S. E.: Dynamics of decadally cycling carbon in subsurface soils, J. Geophys. Res.-Biogeo., 117, G03033, https://doi.org/10.1029/2012JG002034, 2012.

Kothawala, D. N., Moore, T. R., and Hendershot, W. H.: Adsorption of dissolved organic carbon to mineral soils: A comparison of four isotherm approaches, Geoderma, 148, 43-50, https://doi.org/10.1016/j.geoderma.2008.09.004, 2008.

Koven, C. D., Riley, W. J., Subin, Z. M., Tang, J. Y., Torn, M. S., Collins, W. D., Bonan, G. B., Lawrence, D. M., and Swenson, S. C.: The effect of vertically resolved soil biogeochemistry and alternate soil $\mathrm{C}$ and $\mathrm{N}$ models on $\mathrm{C}$ dynamics of CLM4, Biogeosciences, 10, 7109-7131, https://doi.org/10.5194/bg-107109-2013, 2013.

Krinner, G., Viovy, N., de Noblet-Ducoudre, N., Ogee, J., Polcher, J., Friedlingstein, P., Ciais, P., Sitch, S., and Prentice, I. C.: A dynamic global vegetation model for studies of the coupled atmosphere-biosphere system, Global Biogeochem. Cy., 19, GB1015, https://doi.org/10.1029/2003gb002199, 2005.

Kutsch, W. L., Persson, T., Schrumpf, M., Moyano, F. E., Mund, M., Andersson, S., and Schulze, E. D.: Heterotrophic soil respiration and soil carbon dynamics in the deciduous Hainich forest obtained by three approaches, Biogeochemistry, 100, 167-183, https://doi.org/10.1007/s10533-010-9414-9, 2010.

Laine-Kaulio, H., Koivusalo, H., Komarov, A. S., Lappalainen, M., Launiainen, S., and Laurén, A.: Extending the ROMUL model to simulate the dynamics of dissolved and sorbed $\mathrm{C}$ and $\mathrm{N}$ compounds in decomposing boreal mor, Ecol. Model., 272, 277-292, https://doi.org/10.1016/j.ecolmodel.2013.09.026, 2014.

Langerwisch, F., Walz, A., Rammig, A., Tietjen, B., Thonicke, K., and Cramer, W.: Climate change increases riverine carbon 
outgassing, while export to the ocean remains uncertain, Earth Syst. Dynam., 7, 559-582, https://doi.org/10.5194/esd-7-5592016, 2016.

Lauerwald, R., Regnier, P., Camino-Serrano, M., Guenet, B., Guimberteau, M., Ducharne, A., Polcher, J., and Ciais, P.: ORCHILEAK (revision 3875): a new model branch to simulate carbon transfers along the terrestrial-aquatic continuum of the Amazon basin, Geosci. Model Dev., 10, 3821-3859, https://doi.org/10.5194/gmd-10-3821-2017, 2017.

Le Quéré, C., Moriarty, R., Andrew, R. M., Peters, G. P., Ciais, P., Friedlingstein, P., Jones, S. D., Sitch, S., Tans, P., Arneth, A., Boden, T. A., Bopp, L., Bozec, Y., Canadell, J. G., Chini, L. P., Chevallier, F., Cosca, C. E., Harris, I., Hoppema, M., Houghton, R. A., House, J. I., Jain, A. K., Johannessen, T., Kato, E., Keeling, R. F., Kitidis, V., Klein Goldewijk, K., Koven, C., Landa, C. S., Landschützer, P., Lenton, A., Lima, I. D., Marland, G., Mathis, J. T., Metzl, N., Nojiri, Y., Olsen, A., Ono, T., Peng, S., Peters, W., Pfeil, B., Poulter, B., Raupach, M. R., Regnier, P., Rödenbeck, C., Saito, S., Salisbury, J. E., Schuster, U., Schwinger, J., Séférian, R., Segschneider, J., Steinhoff, T., Stocker, B. D., Sutton, A. J., Takahashi, T., Tilbrook, B., van der Werf, G. R., Viovy, N., Wang, Y.-P., Wanninkhof, R., Wiltshire, A., and Zeng, N.: Global carbon budget 2014, Earth Syst. Sci. Data, 7, 47-85, https://doi.org/10.5194/essd-7-47-2015, 2015.

Löfgren, S. and Zetterberg, T.: Decreased DOC concentrations in soil water in forested areas in southern Sweden during 1987-2008, Sci. Total Environ., 409, 1916-1926, https://doi.org/10.1016/j.scitotenv.2011.02.017, 2011.

Luo, Y., Ahlström, A., Allison, S. D., Batjes, N. H., Brovkin, V., Carvalhais, N., Chappell, A., Ciais, P., Davidson, E. A., Finzi, A., Georgiou, K., Guenet, B., Hararuk, O., Harden, J. W., He, Y., Hopkins, F., Jiang, L., Koven, C., Jackson, R. B., Jones, C. D., Lara, M. J., Liang, J., McGuire, A. D., Parton, W., Peng, C., Randerson, J. T., Salazar, A., Sierra, C. A., Smith, M. J., Tian, H., Todd-Brown, K. E. O., Torn, M., Van Groenigen, K. J., Wang, Y. P., West, T. O., Wei, Y., Wieder, W. R., Xia, J., Xu, X., Xu, X., and Zhou, T.: Toward more realistic projections of soil carbon dynamics by Earth system models, Global Biogeochem. Cy., 30, 40-56, https://doi.org/10.1002/2015GB005239, 2016.

MacBean, N., Peylin, P., Chevallier, F., Scholze, M., and Schürmann, G.: Consistent assimilation of multiple data streams in a carbon cycle data assimilation system, Geosci. Model Dev., 9, 3569-3588, https://doi.org/10.5194/gmd-9-3569-2016, 2016.

Manzoni, S., Taylor, P., Richter, A., Porporato, A., and Agren, G. I.: Environmental and stoichiometric controls on microbial carbon-use efficiency in soils, New Phytol., 196, 79-91, https://doi.org/10.1111/j.1469-8137.2012.04225.x, 2012.

Manzoni, S., Čapek, P., Mooshammer, M., Lindahl, B. D., Richter, A., and Šantrůčková, H.: Optimal metabolic regulation along resource stoichiometry gradients, edited by D. Van de Waal, Ecol. Lett., 20, 1182-1191, https://doi.org/10.1111/ele.12815, 2017.

Marschner, B. and Kalbitz, K.: Controls of bioavailability and biodegradability of dissolved organic matter in soils, Geoderma, 113, 211-235, https://doi.org/10.1016/S0016-7061(02)00362-2, 2003.

McGuire, A. D., Hayes, D. J., Kicklighter, D. W., Manizza, M., Zhuang, Q., Chen, M., Follows, M. J., Gurney, K. R., McClelland, J. W., Melillo, J. M., Peterson, B. J., and Prinn, R. G.: An analysis of the carbon balance of the Arctic Basin from 1997 to 2006, Tellus B, 62, 455-474, https://doi.org/10.1111/j.16000889.2010.00497.x, 2010.

Michalzik, B., Tipping, E., Mulder, J., Lancho, J. F. G., Matzner, E., Bryant, C. L., Clarke, N., Lofts, S., and Esteban, M. A. V: Modelling the production and transport of dissolved organic carbon in forest soils, Biogeochemistry, 66, 241-264, 2003.

Moore, T. R., Desouza, W., and Koprivnjak, J. F.: Controls on the Sorption of Dissolved Organic-Carbon by Soils, Soil Sci., 154, 120-129, https://doi.org/10.1097/00010694-199208000-00005, 1992.

Moyano, F. E., Vasilyeva, N., Bouckaert, L., Cook, F., Craine, J., Curiel Yuste, J., Don, A., Epron, D., Formanek, P., Franzluebbers, A., Ilstedt, U., Kätterer, T., Orchard, V., Reichstein, M., Rey, A., Ruamps, L., Subke, J.-A., Thomsen, I. K., and Chenu, C.: The moisture response of soil heterotrophic respiration: interaction with soil properties, Biogeosciences, 9, 1173-1182, https://doi.org/10.5194/bg-9-1173-2012, 2012.

Neff, J. C. and Asner, G. P.: Dissolved organic carbon in terrestrial ecosystems: Synthesis and a model, Ecosystems, 4, 29-48, https://doi.org/10.1007/s100210000058, 2001.

Nishina, K., Ito, A., Beerling, D. J., Cadule, P., Ciais, P., Clark, D. B., Falloon, P., Friend, A. D., Kahana, R., Kato, E., Keribin, R., Lucht, W., Lomas, M., Rademacher, T. T., Pavlick, R., Schaphoff, S., Vuichard, N., Warszawaski, L., and Yokohata, T.: Quantifying uncertainties in soil carbon responses to changes in global mean temperature and precipitation, Earth Syst. Dynam., 5, 197-209, https://doi.org/10.5194/esd-5-197-2014, 2014.

Nodvin, S. C., Driscoll, C. T., and Likens, G. E.: Simple Partitioning of Anions and Dissolved Organic-Carbon in a Forest Soil, Soil Sci., 142, 27-35, https://doi.org/10.1097/00010694-198607000$00005,1986$.

Norby, R. J., Delucia, E. H., Gielen, B., Calfapietra, C., Giardina, C. P., King, J. S., Ledford, J., McCarthy, H. R., Moore, D. J. P., Ceulemans, R., De Angelis, P., Finzi, A. C., Karnosky, D. F., Kubiske, M. E., Lukac, M., Pregitzer, K. S., Scarascia-Mugnozza, G. E., Schlesinger, W. H., and Oren, R.: Forest response to elevated $\mathrm{CO}_{2}$ is conserved across a broad range of productivity, P. Natl. Acad. Sci. USA, 102, 18052 18056, https://doi.org/10.1073/pnas.0509478102, 2005.

O'Brien, B. J. and Stout, J. D.: Movement and Turnover of Soil Organic-Matter as Indicated by Carbon Isotope Measurements, Soil Biol. Biochem., 10, 309-317, https://doi.org/10.1016/00380717(78)90028-7, 1978.

Ota, M., Nagai, H., and Koarashi, J.: Root and dissolved organic carbon controls on subsurface soil carbon dynamics: A model approach, J. Geophys. Res.-Biogeo., 118, 1646-1659, https://doi.org/10.1002/2013jg002379, 2013.

Parton, W. J., Schimel, D. S., Cole, C. V., and Ojima, D. S.: Analysis of factors controlling soil organic matter levels in Great-Plains grasslands, Soil Sci. Soc. Am. J., 51, 1173-1179, 1987.

Parton, W. J., Stewart, J. W. B., and Cole, C. V: Dynamics of C, N, P and $\mathrm{S}$ in grassland soils: a model, Biogeochemistry, 5, 109-131, https://doi.org/10.1007/bf02180320, 1988.

Qualls, R. and Haines, B. L.: Measuring Adsorption Isotherms Using Continuous, Unsaturated Flow through Intact Soil Cores, Soil Sci. Soc. Am. J., 56, 456-460, 1992a. 
Qualls, R. G. and Haines, B. L.: Biodegradability of Dissolved Organic-Matter in Forest Throughfall, Soil Solution, and Stream Water, Soil Sci. Soc. Am. J., 56, 578-586, 1992b.

Regnier, P., Friedlingstein, P., Ciais, P., Mackenzie, F. T., Gruber, N., Janssens, I. A., Laruelle, G. G., Lauerwald, R., Luyssaert, S., Andersson, A. J., Arndt, S., Arnosti, C., Borges, A. V., Dale, A. W., Gallego-Sala, A., Goddéris, Y., Goossens, N., Hartmann, J., Heinze, C., Ilyina, T., Joos, F., LaRowe, D. E., Leifeld, J., Meysman, F. J. R., Munhoven, G., Raymond, P. A., Spahni, R., Suntharalingam, P., and Thullner, M.: Anthropogenic perturbation of the carbon fluxes from land to ocean, Nat. Geosci., 6, 597-607, https://doi.org/10.1038/ngeo1830, 2013.

Rumpel, C. and Kogel-Knabner, I.: Deep soil organic matter-a key but poorly understood component of terrestrial C cycle, Plant Soil, 338, 143-158, https://doi.org/10.1007/s11104-010-0391-5, 2011.

Ryan, E. M., Ogle, K., Peltier, D., Walker, A. P., De Kauwe, M. G., Medlyn, B. E., Williams, D. G., Parton, W., Asao, S., Guenet, B., Harper, A. B., Lu, X., Luus, K. A., Zaehle, S., Shu, S., Werner, C., Xia, J., and Pendall, E.: Gross primary production responses to warming, elevated $\mathrm{CO}_{2}$, and irrigation: quantifying the drivers of ecosystem physiology in a semiarid grassland, Glob. Change Biol., 23, 3092-3106, https://doi.org/10.1111/gcb.13602, 2017.

Schmidt, M. W. I., Torn, M. S., Abiven, S., Dittmar, T., Guggenberger, G., Janssens, I. A., Kleber, M., Kögel-Knabner, I., Lehmann, J., Manning, D. A. C., Nannipieri, P., Rasse, D. P., Weiner, S., and Trumbore, S. E.: Persistence of soil organic matter as an ecosystem property, Nature, 478, 49-56, https://doi.org/10.1038/nature10386, 2011.

Schrumpf, M., Kaiser, K., Guggenberger, G., Persson, T., KögelKnabner, I., and Schulze, E.-D.: Storage and stability of organic carbon in soils as related to depth, occlusion within aggregates, and attachment to minerals, Biogeosciences, 10, 16751691, https://doi.org/10.5194/bg-10-1675-2013, 2013.

Schulze, E. D., Luyssaert, S., Ciais, P., Freibauer, A., Janssens, I. A., Soussana, J. F., Smith, P., Grace, J., Levin, I., Thiruchittampalam, B., Heimann, M., Dolman, A. J., Valentini, R., Bousquet, P., Peylin, P., Peters, W., Rodenbeck, C., Etiope, G., Vuichard, N., Wattenbach, M., Nabuurs, G. J., Poussi, Z., Nieschulze, J., Gash, J. H., and Team, C.: Importance of methane and nitrous oxide for Europe's terrestrial greenhouse-gas balance, Nat. Geosci., 2, 842-850, https://doi.org/10.1038/Ngeo686, 2009.

Sinsabaugh, R. L., Manzoni, S., Moorhead, D. L., and Richter, A.: Carbon use efficiency of microbial communities: stoichiometry, methodology and modelling, Ecol. Lett., 16, 930-939, https://doi.org/10.1111/Ele.12113, 2013.

Sinsabaugh, R. L., Turner, B. L., Talbot, J. M., Waring, B. G., Powers, J. S., Kuske, C. R., Moorhead, D. L., and Follstad Shah, J. J.: Stoichiometry of microbial carbon use efficiency in soils, Ecol. Monogr., 86, 172-189, https://doi.org/10.1890/15-2110.1, 2016.

Sulman, B. N., Phillips, R. P., Oishi, A. C., Shevliakova, E., and Pacala, S. W.: Microbe-driven turnover offsets mineral-mediated storage of soil carbon under elevated $\mathrm{CO}_{2}$, Nat. Clim. Change, 4 , 1099-1102, https://doi.org/10.1038/Nclimate2436, 2014.

Tian, H., Yang, Q., Najjar, R. G., Ren, W., Friedrichs, M. A. M., Hopkinson, C. S., and Pan, S.: Anthropogenic and climatic influences on carbon fluxes from eastern North America to the At- lantic Ocean: A process-based modeling study, J. Geophys. Res.Biogeo., 120, 757-772, https://doi.org/10.1002/2014JG002760, 2015.

Todd-Brown, K. E. O., Randerson, J. T., Post, W. M., Hoffman, F. M., Tarnocai, C., Schuur, E. A. G., and Allison, S. D.: Causes of variation in soil carbon simulations from CMIP5 Earth system models and comparison with observations, Biogeosciences, 10, 1717-1736, https://doi.org/10.5194/bg-10-1717-2013, 2013.

Todd-Brown, K. E. O., Randerson, J. T., Hopkins, F., Arora, V., Hajima, T., Jones, C., Shevliakova, E., Tjiputra, J., Volodin, E., Wu, T., Zhang, Q., and Allison, S. D.: Changes in soil organic carbon storage predicted by Earth system models during the 21st century, Biogeosciences, 11, 2341-2356, https://doi.org/10.5194/bg-11-2341-2014, 2014.

Turgeon, J.: Production and biodegradation of dissolved carbon, nitrogen and phosporous from Canadian forest floors, McGill University, Montreal, 2008.

Vuichard, N. and Papale, D.: Filling the gaps in meteorological continuous data measured at FLUXNET sites with ERA-Interim reanalysis, Earth Syst. Sci. Data, 7, 157-171, https://doi.org/10.5194/essd-7-157-2015, 2015.

Walmsley, D. C.: Quantifying Dissolved Carbon and Nitrogen 60 Losses from Soils Subjected to Different Land-use and Management Practices, University College Dublin, available at: https: //books.google.es/books?id=HCz2ZwEACAAJ (last access: 29 September 2017), 2009.

Walmsley, D. C., Siemens, J., Kindler, R., Kirwan, L., Kaiser, K., Saunders, M., Kaupenjohann, M., and Osborne, B. A.: Dissolved carbon leaching from an Irish cropland soil is increased by reduced tillage and cover cropping, Agr. Ecosyst. Environ., 142, 393-402, https://doi.org/10.1016/j.agee.2011.06.011, 2011.

Wieder, W. R., Cleveland, C. C., Smith, W. K., and ToddBrown, K.: Future productivity and carbon storage limited by terrestrial nutrient availability, Nat. Geosci., 8, 441-444, https://doi.org/10.1038/ngeo2413, 2015.

Wu, H., Peng, C., Moore, T. R., Hua, D., Li, C., Zhu, Q., Peichl, M., Arain, M. A., and Guo, Z.: Modeling dissolved organic carbon in temperate forest soils: TRIPLEX-DOC model development and validation, Geosci. Model Dev., 7, 867-881, https://doi.org/10.5194/gmd-7-867-2014, 2014.

Wynn, J. G., Bird, M. I., and Wong, V. N. L.: Rayleigh distillation and the depth profile of ${ }^{13} \mathrm{C} /{ }^{12} \mathrm{C}$ ratios of soil organic carbon from soils of disparate texture in Iron Range National Park, Far North Queensland, Australia, Geochim. Cosmochim. Ac., 69, 1961-1973, 2005.

Zaehle, S., Sitch, S., Smith, B., and Hatterman, F.: Effects of parameter uncertainties on the modeling of terrestrial biosphere dynamics, Global Biogeochem. Cy., 19, Gb3020, https://doi.org/10.1029/2004gb002395, 2005.

Zhang, D., Hui, D., Luo, Y., and Zhou, G.: Rates of litter decomposition in terrestrial ecosystems: global patterns and controlling factors, J. Plant Ecol., 1, 85-93, https://doi.org/10.1093/jpe/rtn002, 2008. 